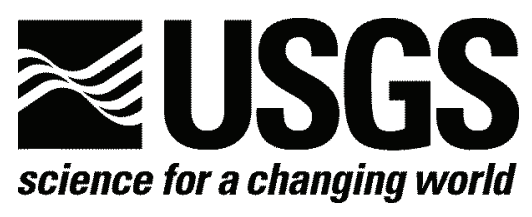

\title{
Mining Claim Activity on Federal Land for the Period 1976 through 2003
}

By J. Douglas Causey

Digital Series 124

U.S. Department of the Interior

U.S. Geological Survey 


\section{Contents}

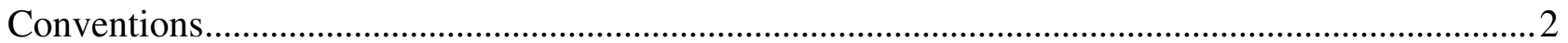

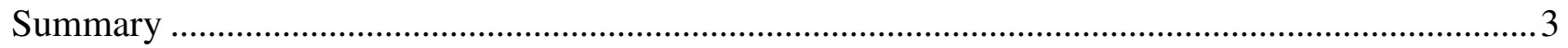

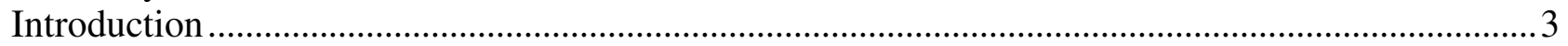

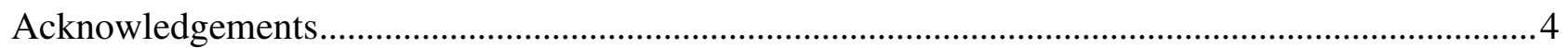

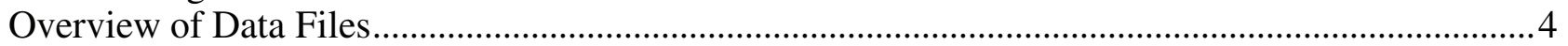

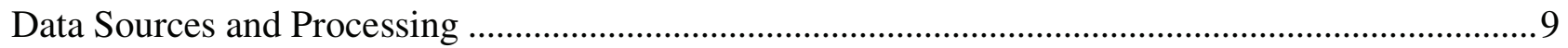

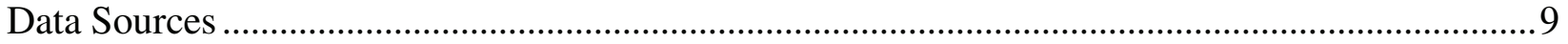

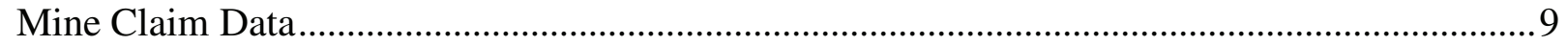

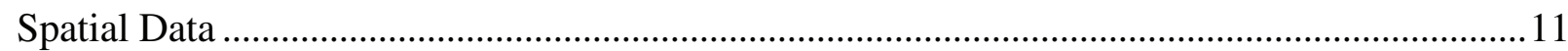

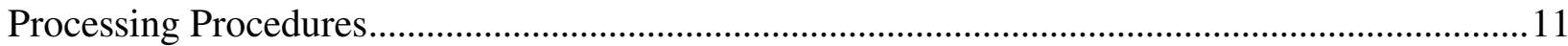

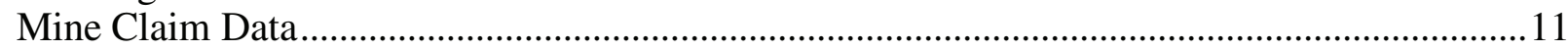

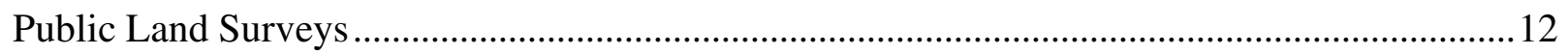

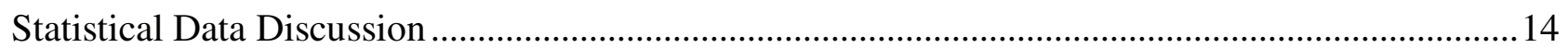

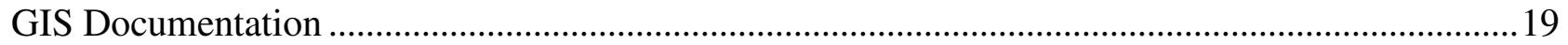

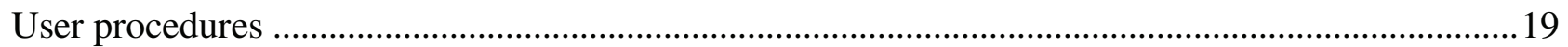

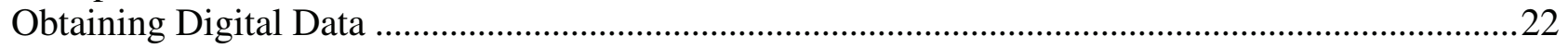

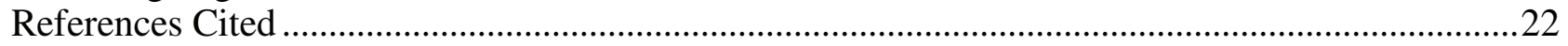

Appendix A - Table Design SQL (Structured Query Language) ...................................................2

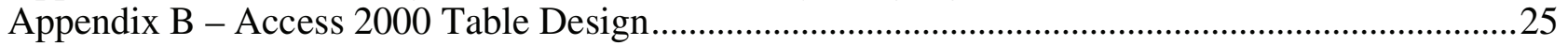

\section{Conventions}

Database table names are in small caps; for example CASE_TBL.

Database field names are in italics; for example mtrs. 


\title{
Mining Claim Activity on Federal Lands, 1976-2003
}

\author{
By J. Douglas Causey
}

\section{Summary}

Previous reports on mining claim records (Campbell, 1996, Campbell and Hyndman, 1996, Hyndman, 1999) provided information and statistics (number of claims) using data from the U.S. Bureau of Land Management's (BLM) Mining Claim Recordation System. Since that time, BLM converted their mining claim data to the Legacy Repost 2000 system (LR2000).

This report describes a process to extract similar statistical data about mining claims from LR2000 data using different software and procedures than were used in the earlier work. A major difference between this process and the previous work is that every section that has a mining claim record is assigned a value. This is done by proportioning a claim between each section in which it is recorded. Also, the mining claim data in this report includes all BLM records, not just the western states.

LR2000 mining claim database tables for the United States were provided by BLM in text format and imported into a Microsoft ${ }^{\circledR}$ Access 2000 database in January, 2004. Data from two tables in the BLM LR2000 database were summarized through a series of database queries to determine a number that represents active mining claims in each Public Land Survey (PLS) section for each of the years from 1976 to 2002

For most of the area, spatial databases are also provided. The spatial databases are only configured to work with the statistics provided in the non-spatial data files. They are suitable for geographic information system (GIS)-based regional assessments at a scale of 1:100,000 or smaller (that is, 1:250,000).

\section{Introduction}

The U.S. Bureau of Mines (USBM) initiated a process of examining exploration activity on Federal Lands using the U.S. Bureau of Land Management (BLM) mining claim recordation system. After the closure of the USBM in 1995, that activity was continued by the U.S. Geological Survey. Campbell (1996) described the procedure used to process the data using ESRI® ArcInfo and dBASE® software. Results current to 1996 were published for Washington, Idaho, and Oregon by Campbell and Hyndman (1996) and an update of those states plus Arizona, California, Colorado, Montana, Nebraska, New Mexico, Nevada, South Dakota, Utah, and Wyoming was published by Hyndman (1999).

Demand for information about mining claim activity by Federal Land Managing agencies, along with computer hardware and software improvements has spurred the development of a system that will allow regular updates of mining claim statistics in a timely manner. This report describes a new system to accomplish that task.

BLM records four types of location notices in their database: lode claim, placer claim, tunnel site, and mill site. Almost $85 \%$ of the notices are for lode claims, and about $12.8 \%$ are for placer claims. Mill sites make up less than $2.2 \%$ of the locations notices, and about $0.06 \%$ are tunnel sites. Throughout this report all these notices are referred to as claims.

One of the main uses of the data is in spatial analysis. In order to provide the user with appropriate spatial data, a search for public domain PLS spatial databases was included in this project. BLM's effort to create high quality PLS spatial databases is far from completion. Many other Public Domain spatial databases are incomplete or contain numerous errors. Although most of the claims in South Dakota are in the western part of the state, the only publicly available PLS spatial data covers the eastern half of the state. 
Public spatial databases are provided for most states in which mining claims have been recorded. The exceptions are South Dakota, which did not have spatial data for the area containing claims; and North Dakota, which only has two claims. The PLS sections, except in the Dakotas, in which at least part of a mining claim was listed as being active by BLM in 2003 are shown in figure 1.

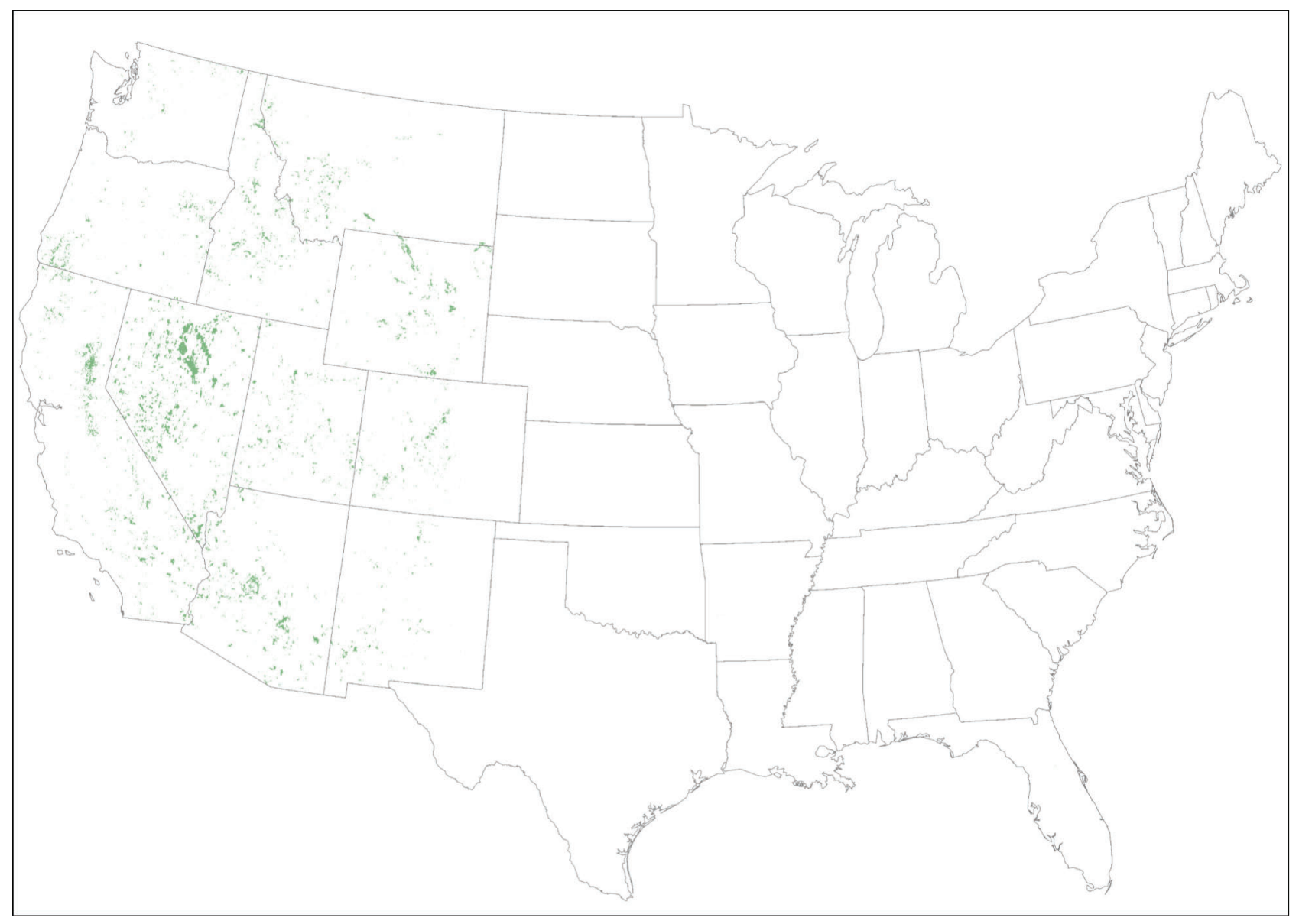

Figure 1. Public Land Survey sections (green colored) in which there was a mining claim in 2003.

\section{Acknowledgements}

I would like to thank Cheryl Laudenbach and Leslie Cone, BLM for providing the LR2000 data. I also thank Dave Frank and Gary Raines for their technical review of the report.

\section{Overview of Data Files}

The data for mining claim activity are provided in several files organized by state that are listed and briefly described in table 1. The dBASE (.dbf) and ASCII (.txt) files provide two versions of the same statistical summary data in a proprietary and non- proprietary format, respectively.

The summary non-spatial data files include:

- number of all claims (sum of lode, placer, tunnel site, and mill site) in each section, by year (for example, files az_claim.dbf, az_claim.txt),

- number of lode claims in each section, by year (for example, files az_lode.dbf, az_lode.txt), 
- number of placer claims in each section, by year (for example, files az_placr.dbf, az_placr.txt), and

- total number of claims in each section by status (active or closed) at end of 2003 and type (lode, placer, mill site, tunnel site) (for example, files az_total.dbf, az_total.txt).

While the data was processed using Access, neither the original data nor the Access databases used for this analysis are supplied with this report. There are two practical reasons to not include the source data. First, the data is time stamped. It is a snapshot of the BLM LR2000 database that is only valid for January, 15, 2004 when it was extracted. Another extraction of data will produce different statistics. Second, the data is massive. The files provided by BLM exceeded $700 \mathrm{MB}$ (megabytes), compressed. The Access databases created from this data total 4 gigabytes (GB) in size, the largest, Nevada, being 1.2 GB. These Access databases will only compress to about $530 \mathrm{MB}$.

State spatial databases provide PLS section polygons to which a user can attach data from the summary tables. The spatial databases are in shapefile format. FGDC-compliant ${ }^{1}$ metadata provides information about the spatial databases and includes information about data sources, data quality, projection, and how to obtain the data on the World Wide Web, in addition to providing a data dictionary (metadata) for the information in the database tables. All spatial databases contain metadata that can be read in ESRI's ArcCatalog module ${ }^{2}$.

Table 1. List of digital files provided in this data release.

\begin{tabular}{|c|c|}
\hline \multicolumn{2}{|r|}{ File Description } \\
\hline \multicolumn{2}{|c|}{$\begin{array}{l}\text { Spatial Databases } \\
\text { Shapefile filenames are listed as they are displayed and viewed in ArcCatalog (for example, az_pls_03.shp) ESRI } \\
\text { shapefiles consist of a collection of files with the extensions dbf, mtrs.atx, prj, sbn, shp, shp.xml, and shx. ArcCatalog } \\
\text { only displays the shp extension (and hides all the others) in a directory listing, whereas the operating system directory } \\
\text { listings will show the complete collection of files. }\end{array}$} \\
\hline az_pls_03.shp & $\begin{array}{l}\text { Public Land Survey System sections in which mining claims have been recorded with BLM in } \\
\text { Arizona (ESRI shapefile format) }\end{array}$ \\
\hline ar_pls_03.shp & $\begin{array}{l}\text { Public Land Survey System sections in which mining claims have been recorded with BLM in } \\
\text { Arkansas (ESRI shapefile format) }\end{array}$ \\
\hline ca_pls_03.shp & $\begin{array}{l}\text { Public Land Survey System sections in which mining claims have been recorded with BLM in } \\
\text { California (ESRI shapefile format) }\end{array}$ \\
\hline co_pls_03.shp & $\begin{array}{l}\text { Public Land Survey System section in which mining claims have been recorded with BLM in } \\
\text { Colorado (ESRI shapefile format) }\end{array}$ \\
\hline fl_pls_03.shp & $\begin{array}{l}\text { Public Land Survey System sections in which mining claims have been recorded with BLM in } \\
\text { Florida (ESRI shapefile format) }\end{array}$ \\
\hline id_pls_03.shp & $\begin{array}{l}\text { Public Land Survey System sections in which mining claims have been recorded with BLM in } \\
\text { Idaho (ESRI shapefile format) }\end{array}$ \\
\hline mt_pls_03.shp & $\begin{array}{l}\text { Public Land Survey System sections in which mining claims have been recorded with BLM in } \\
\text { Montana (ESRI shapefile format) }\end{array}$ \\
\hline ne_pls_03.shp & $\begin{array}{l}\text { Public Land Survey System sections in which mining claims have been recorded with BLM in } \\
\text { Nebraska (ESRI shapefile format) }\end{array}$ \\
\hline nm_pls_03.shp & $\begin{array}{l}\text { Public Land Survey System sections in which mining claims have been recorded with BLM in } \\
\text { New Mexico (ESRI shapefile format) }\end{array}$ \\
\hline nv_pls_03.shp & $\begin{array}{l}\text { Public Land Survey System sections in which mining claims have been recorded with BLM in } \\
\text { Nevada (ESRI shapefile format) }\end{array}$ \\
\hline or_pls_03.shp & $\begin{array}{l}\text { Public Land Survey System sections in which mining claims have been recorded with BLM in } \\
\text { Oregon (ESRI shapefile format) }\end{array}$ \\
\hline ut_pls_03.shp & $\begin{array}{l}\text { Public Land Survey System sections in which mining claims have been recorded with BLM in } \\
\text { Utah (ESRI shapefile format) }\end{array}$ \\
\hline wa_pls_03.shp & $\begin{array}{l}\text { Public Land Survey System sections in which mining claims have been recorded with BLM in } \\
\text { Washington (ESRI shapefile format) }\end{array}$ \\
\hline
\end{tabular}

\footnotetext{
${ }^{1}$ Federal Geographic Data Committee (http://www.fgdc.gov)

${ }^{2}$ ArcGIS, version 8 (http://www.esri.com)
} 


\begin{tabular}{|c|c|}
\hline File Name & File Description \\
\hline wy_pls_03.shp & $\begin{array}{l}\text { Public Land Survey System sections in which mining claims have been recorded with BLM in } \\
\text { Wyoming (ESRI shapefile format) }\end{array}$ \\
\hline \multicolumn{2}{|c|}{$\begin{array}{l}\text { Metadata } \\
\text { State-specific metadata files are provided in two different file formats: embedded shapefile format (.shp.xml filename } \\
\text { extension) and HTML format (.htm filename extension). }\end{array}$} \\
\hline Metadata.txt & $\begin{array}{l}\text { General description of information in the spatial mining claim databases (shapefiles) in a } \\
\text { parseable ASCII text format. (Information specific to each state's spatial data base is provided } \\
\text { in separate metadata files for each state.) }\end{array}$ \\
\hline $\begin{array}{l}\text { az_pls_03.shp.xml, } \\
\text { az_pls_03.htm }\end{array}$ & Description of information specific to the Arizona spatial database (az_pls_03.shp). \\
\hline az_claims.pdf & $\begin{array}{l}\text { Graphic image, created in ArcGIS, showing sections in Arizona where claims have been active } \\
\text { between } 1976 \text { and } 2003 \text {. }\end{array}$ \\
\hline $\begin{array}{l}\text { ar_pls_03.shp.xml, } \\
\text { ar_pls_03.htm }\end{array}$ & Description of information specific to the Arkansas spatial database (az_pls_03.shp). \\
\hline ar_claims.pdf & $\begin{array}{l}\text { Graphic image, created in ArcGIS, showing sections in Arkansas where claims have been } \\
\text { active between } 1976 \text { and } 2003 \text {. }\end{array}$ \\
\hline $\begin{array}{l}\text { ca_pls_03.shp.xml, } \\
\text { ca_pls_03.htm }\end{array}$ & Description of information specific to the California spatial database (az_pls_03.shp). \\
\hline ca_claims.pdf & $\begin{array}{l}\text { Graphic image, created in ArcGIS, showing sections in California where claims have been } \\
\text { active between } 1976 \text { and } 2003 \text {. }\end{array}$ \\
\hline $\begin{array}{l}\text { co_pls_03.shp.xml, } \\
\text { co_pls_03.htm }\end{array}$ & Description of information specific to the Colorado spatial database (az_pls_03.shp). \\
\hline co_claims.pdf & $\begin{array}{l}\text { Graphic image, created in ArcGIS, showing sections in Colorado where claims have been } \\
\text { active between } 1976 \text { and } 2003 \text {. }\end{array}$ \\
\hline $\begin{array}{l}\text { fl_pls_03.shp.xml, } \\
\text { fl_pls_03.htm }\end{array}$ & Description of information specific to the Florida spatial database (az_pls_03.shp). \\
\hline fl_claims.pdf & $\begin{array}{l}\text { Graphic image, created in ArcGIS, showing sections in Florida where claims have been active } \\
\text { between } 1976 \text { and } 2003 \text {. }\end{array}$ \\
\hline $\begin{array}{l}\text { id_pls_03.shp.xml, } \\
\text { id_pls_03.htm }\end{array}$ & Description of information specific to the Idaho spatial database (az_pls_03.shp). \\
\hline id_claims.pdf & $\begin{array}{l}\text { Graphic image, created in ArcGIS, showing sections in Idaho where claims have been active } \\
\text { between } 1976 \text { and } 2003 \text {. }\end{array}$ \\
\hline $\begin{array}{l}\text { mt_pls_03.shp.xml, } \\
\text { mt_pls_03.htm }\end{array}$ & Description of information specific to the Montana spatial database (az_pls_03.shp). \\
\hline mt_claims.pdf & $\begin{array}{l}\text { Graphic image, created in ArcGIS, showing sections in Montana where claims have been active } \\
\text { between } 1976 \text { and } 2003 \text {. }\end{array}$ \\
\hline $\begin{array}{l}\text { ne_pls_03.shp.xml, } \\
\text { ne_pls_03.htm }\end{array}$ & Description of information specific to the Nebraska spatial database (az_pls_03.shp). \\
\hline ne_claims.pdf & $\begin{array}{l}\text { Graphic image, created in ArcGIS, showing sections in Nebraska where claims have been } \\
\text { active between } 1976 \text { and } 2003 \text {. }\end{array}$ \\
\hline $\begin{array}{l}\text { nm_pls_03.shp.xml, } \\
\text { nm_pls_03.htm }\end{array}$ & Description of information specific to the New Mexico spatial database (az_pls_03.shp). \\
\hline nm_claims.pdf & $\begin{array}{l}\text { Graphic image, created in ArcGIS, showing sections in New Mexico where claims have been } \\
\text { active between } 1976 \text { and } 2003 \text {. }\end{array}$ \\
\hline $\begin{array}{l}\text { nv_pls_03.shp.xml, } \\
\text { nv_pls_03.htm }\end{array}$ & Description of information specific to the Nevada spatial database (az_pls_03.shp). \\
\hline nv_claims.pdf & $\begin{array}{l}\text { Graphic image, created in ArcGIS, showing sections in Nevada where claims have been active } \\
\text { between } 1976 \text { and } 2003 \text {. }\end{array}$ \\
\hline $\begin{array}{l}\text { or_pls_03.shp.xml, } \\
\text { or_pls_03.htm }\end{array}$ & Description of information specific to the Oregon spatial database (az_pls_03.shp). \\
\hline or_claims.pdf & $\begin{array}{l}\text { Graphic image, created in ArcGIS, showing sections in Oregon where claims have been active } \\
\text { between } 1976 \text { and } 2003 \text {. }\end{array}$ \\
\hline $\begin{array}{l}\text { ut_pls_03.shp.xml, } \\
\text { ut_pls_03.htm }\end{array}$ & Description of information specific to the Utah spatial database (az_pls_03.shp). \\
\hline ut_claims.pdf & $\begin{array}{l}\text { Graphic image, created in ArcGIS, showing sections in Utah where claims have been active } \\
\text { between } 1976 \text { and } 2003 \text {. }\end{array}$ \\
\hline
\end{tabular}




\begin{tabular}{|c|c|}
\hline File Name & File Description \\
\hline $\begin{array}{l}\text { wa_pls_03.shp.xml, } \\
\text { wa_pls_03.htm }\end{array}$ & Description of information specific to the Washington spatial database (az_pls_03.shp). \\
\hline wa_claims.pdf & $\begin{array}{l}\text { Graphic image, created in ArcGIS, showing sections in Washington where claims have been } \\
\text { active between } 1976 \text { and } 2003 .\end{array}$ \\
\hline $\begin{array}{l}\text { wy_pls_03.shp.xml, } \\
\text { wy_pls_03.htm }\end{array}$ & Description of information specific to the Wyoming spatial database (az_pls_03.shp). \\
\hline wy_claims.pdf & $\begin{array}{l}\text { Graphic image, created in ArcGIS, showing sections in Wyoming where claims have been } \\
\text { active between } 1976 \text { and } 2003 \text {. }\end{array}$ \\
\hline \multicolumn{2}{|c|}{$\begin{array}{l}\text { Non-Spatial Data Files } \\
\text { Each database is provided in two different file formats: dBASE format (.dbf file name extension) and ASCII text } \\
\text { format (.txt file name extension). }\end{array}$} \\
\hline $\begin{array}{l}\text { az_claim.dbf, } \\
\text { az_claim.txt }\end{array}$ & $\begin{array}{l}\text { Database of mining claim intensity: total for all claim types (lode, placer, tunnel site, and mill } \\
\text { site), by PLS section and year for Arizona, 1976-2003. }\end{array}$ \\
\hline $\begin{array}{l}\text { az_lode.dbf, } \\
\text { az_lode.txt }\end{array}$ & $\begin{array}{l}\text { Database of mining claim intensity totaled for lode claims, by PLS section and year for } \\
\text { Arizona, 1976-2003. }\end{array}$ \\
\hline $\begin{array}{l}\text { az_placr.dbf, } \\
\text { az_placr.txt }\end{array}$ & $\begin{array}{l}\text { Database of mining claim intensity totaled for placer claims, by PLS section and year for } \\
\text { Arizona, 1976-2003. }\end{array}$ \\
\hline $\begin{array}{l}\text { az_total.dbf, } \\
\text { az_total.txt }\end{array}$ & $\begin{array}{l}\text { Database of all mining claims for the period 1976-2003; by PLS section, claim type (lode, } \\
\text { placer, mill site, tunnel site), and claims status (Active or Closed) at end of } 2003 \text { for Arizona. }\end{array}$ \\
\hline $\begin{array}{l}\text { ar_claim.dbf, } \\
\text { ar_claim.txt }\end{array}$ & $\begin{array}{l}\text { Database of mining claim intensity: total for all claim types (lode, placer, tunnel site, and mill } \\
\text { site), by PLS section and year for Arkansas, 1976-2003. }\end{array}$ \\
\hline $\begin{array}{l}\text { ar_lode.dbf, } \\
\text { ar_lode.txt }\end{array}$ & $\begin{array}{l}\text { Database of mining claim intensity totaled for lode claims, by PLS section and year for } \\
\text { Arkansas, 1976-2003. }\end{array}$ \\
\hline $\begin{array}{l}\text { ar_placr.dbf, } \\
\text { ar_placr.txt }\end{array}$ & $\begin{array}{l}\text { Database of mining claim intensity totaled for placer claims, by PLS section and year for } \\
\text { Arkansas, 1976-2003. }\end{array}$ \\
\hline $\begin{array}{l}\text { ar_total.dbf, } \\
\text { ar_total.txt }\end{array}$ & $\begin{array}{l}\text { Database of all mining claims for the period 1976-2003; by PLS section, claim type (lode, } \\
\text { placer, mill site, tunnel site), and claims status (Active or Closed) at end of } 2003 \text { for Arkansas. }\end{array}$ \\
\hline $\begin{array}{l}\text { ca_claim.dbf, } \\
\text { ca_claim.txt }\end{array}$ & $\begin{array}{l}\text { Database of mining claim intensity: total for all claim types (lode, placer, tunnel site, and mill } \\
\text { site), by PLS section and year for California, 1976-2003. }\end{array}$ \\
\hline $\begin{array}{l}\text { ca_lode.dbf, } \\
\text { ca_lode.txt }\end{array}$ & $\begin{array}{l}\text { Database of mining claim intensity totaled for lode claims, by PLS section and year for } \\
\text { California, 1976-2003. }\end{array}$ \\
\hline $\begin{array}{l}\text { ca_placr.dbf, } \\
\text { ca_placr.txt }\end{array}$ & $\begin{array}{l}\text { Database of mining claim intensity totaled for placer claims, by PLS section and year for } \\
\text { California, 1976-2003. }\end{array}$ \\
\hline $\begin{array}{l}\text { ca_total.dbf, } \\
\text { ca_total.txt }\end{array}$ & $\begin{array}{l}\text { Database of all mining claims for the period 1976-2003; by PLS section, claim type (lode, } \\
\text { placer, tunnel site, and mill site), and claims status (Active or Closed) at end of } 2003 \text { for } \\
\text { California. }\end{array}$ \\
\hline $\begin{array}{l}\text { co_claim.dbf, } \\
\text { co_claim.txt }\end{array}$ & $\begin{array}{l}\text { Database of mining claim intensity: total for all claim types (lode, placer, tunnel site, and mill } \\
\text { site), by PLS section and year for Colorado, 1976-2003. }\end{array}$ \\
\hline $\begin{array}{l}\text { co_lode.dbf, } \\
\text { co_lode.txt }\end{array}$ & $\begin{array}{l}\text { Database of mining claim intensity totaled for lode claims, by PLS section and year for } \\
\text { Colorado, 1976-2003. }\end{array}$ \\
\hline $\begin{array}{l}\text { co_placr.dbf, } \\
\text { co_placr.txt }\end{array}$ & $\begin{array}{l}\text { Database of mining claim intensity totaled for placer claims, by PLS section and year for } \\
\text { Colorado, 1976-2003. }\end{array}$ \\
\hline $\begin{array}{l}\text { co_total.dbf, } \\
\text { co_total.txt }\end{array}$ & $\begin{array}{l}\text { Database of all mining claims for the period 1976-2003; by PLS section, claim type (lode, } \\
\text { placer, tunnel site, and mill site), and claims status (Active or Closed) at end of } 2003 \text { for } \\
\text { Colorado. }\end{array}$ \\
\hline $\begin{array}{l}\text { fl_claim.dbf, } \\
\text { fl_claim.txt }\end{array}$ & $\begin{array}{l}\text { Database of mining claim intensity: total for all claim types (lode, placer, tunnel site, and mill } \\
\text { site), by PLS section and year for Florida, 1976-2003. }\end{array}$ \\
\hline $\begin{array}{l}\text { fl_lode.dbf, } \\
\text { fl_lode.txt }\end{array}$ & $\begin{array}{l}\text { Database of mining claim intensity totaled for lode claims, by PLS section and year for Florida, } \\
\text { 1976-2003. }\end{array}$ \\
\hline $\begin{array}{l}\text { fl_placr.dbf, } \\
\text { fl_placr.txt }\end{array}$ & $\begin{array}{l}\text { Database of mining claim intensity totaled for placer claims, by PLS section and year for } \\
\text { Florida, 1976-2003. }\end{array}$ \\
\hline
\end{tabular}




\begin{tabular}{|c|c|}
\hline File Name & File Description \\
\hline $\begin{array}{l}\text { fl_total.dbf, } \\
\text { fl_total.txt }\end{array}$ & $\begin{array}{l}\text { Database of all mining claims for the period 1976-2003; by PLS section, claim type (lode, } \\
\text { placer, tunnel site, and mill site), and claims status (Active or Closed) at end of } 2003 \text { for } \\
\text { Florida. }\end{array}$ \\
\hline $\begin{array}{l}\text { id_claim.dbf, } \\
\text { id_claim.txt }\end{array}$ & $\begin{array}{l}\text { Database of mining claim intensity: total for all claim types (lode, placer, tunnel site, and mill } \\
\text { site), by PLS section and year for Idaho, 1976-2003. }\end{array}$ \\
\hline $\begin{array}{l}\text { id_lode.dbf, } \\
\text { id_lode.txt }\end{array}$ & $\begin{array}{l}\text { Database of mining claim intensity totaled for lode claims, by PLS section and year for Idaho, } \\
\text { 1976-2003. }\end{array}$ \\
\hline $\begin{array}{l}\text { id_placr.dbf, } \\
\text { id_placr.txt }\end{array}$ & $\begin{array}{l}\text { Database of mining claim intensity totaled for placer claims, by PLS section and year for Idaho, } \\
\text { 1976-2003. }\end{array}$ \\
\hline $\begin{array}{l}\text { id_total.dbf, } \\
\text { id_total.txt }\end{array}$ & $\begin{array}{l}\text { Database of all mining claims for the period 1976-2003; by PLS section, claim type (lode, } \\
\text { placer, tunnel site, and mill site), and claims status (Active or Closed) at end of } 2003 \text { for Idaho. }\end{array}$ \\
\hline $\begin{array}{l}\text { mt_claim.dbf, } \\
\text { mt_claim.txt }\end{array}$ & $\begin{array}{l}\text { Database of mining claim intensity: total for all claim types (lode, placer, tunnel site, and mill } \\
\text { site), by PLS section and year for Montana, } 1976-2003 \text {. }\end{array}$ \\
\hline $\begin{array}{l}\text { mt_lode.dbf, } \\
\text { mt_lode.txt }\end{array}$ & $\begin{array}{l}\text { Database of mining claim intensity totaled for lode claims, by PLS section and year for } \\
\text { Montana, 1976-2003. }\end{array}$ \\
\hline $\begin{array}{l}\text { mt_placr.dbf, } \\
\text { mt_placr.txt }\end{array}$ & $\begin{array}{l}\text { Database of mining claim intensity totaled for placer claims, by PLS section and year for } \\
\text { Montana, 1976-2003. }\end{array}$ \\
\hline $\begin{array}{l}\text { mt_total.dbf, } \\
\text { mt_total.txt }\end{array}$ & $\begin{array}{l}\text { Database of all mining claims for the period 1976-2003; by PLS section, claim type (lode, } \\
\text { placer, tunnel site, and mill site), and claims status (Active or Closed) at end of } 2003 \text { for } \\
\text { Montana. }\end{array}$ \\
\hline $\begin{array}{l}\text { ne_claim.dbf, } \\
\text { ne claim.txt }\end{array}$ & $\begin{array}{l}\text { Database of mining claim intensity: total for all claim types (lode, placer, tunnel site, and mill } \\
\text { site), by PLS section and year for Nebraska. } 1976-2003 \text {. }\end{array}$ \\
\hline $\begin{array}{l}\text { ne_lode.dbf, } \\
\text { ne_lode.txt }\end{array}$ & $\begin{array}{l}\text { Database of mining claim intensity totaled for lode claims, by PLS section and year for } \\
\text { Nebraska, 1976-2003. }\end{array}$ \\
\hline $\begin{array}{l}\text { ne_placr.dbf, } \\
\text { ne_placr.txt }\end{array}$ & $\begin{array}{l}\text { Database of mining claim intensity totaled for placer claims, by PLS section and year for } \\
\text { Nebraska, 1976-2003. }\end{array}$ \\
\hline $\begin{array}{l}\text { ne_total.dbf, } \\
\text { ne_total.txt }\end{array}$ & $\begin{array}{l}\text { Database of all mining claims for the period 1976-2003; by PLS section, claim type (lode, } \\
\text { placer, tunnel site, and mill site), and claims status (Active or Closed) at end of } 2003 \text { for } \\
\text { Nebraska. }\end{array}$ \\
\hline $\begin{array}{l}\text { nm_claim.dbf, } \\
\text { nm_claim.txt }\end{array}$ & $\begin{array}{l}\text { Database of mining claim intensity: total for all claim types (lode, placer, tunnel site, and mill } \\
\text { site), by PLS section and year for New Mexico, 1976-2003. }\end{array}$ \\
\hline $\begin{array}{l}\text { nm_lode.dbf, } \\
\text { nm_lode.txt }\end{array}$ & $\begin{array}{l}\text { Database of mining claim intensity totaled for lode claims, by PLS section and year for New } \\
\text { Mexico, 1976-2003. }\end{array}$ \\
\hline $\begin{array}{l}\text { nm_placr.dbf, } \\
\text { nm_placr.txt }\end{array}$ & $\begin{array}{l}\text { Database of mining claim intensity totaled for placer claims, by PLS section and year for New } \\
\text { Mexico, 1976-2003. }\end{array}$ \\
\hline $\begin{array}{l}\text { nm_total.dbf, } \\
\text { nm_total.txt }\end{array}$ & $\begin{array}{l}\text { Database of all mining claims for the period 1976-2003; by PLS section, claim type (lode, } \\
\text { placer, tunnel site, and mill site), and claims status (Active or Closed) at end of } 2003 \text { for New } \\
\text { Mexico. }\end{array}$ \\
\hline $\begin{array}{l}\text { nv_claim.dbf, } \\
\text { nv_claim.txt }\end{array}$ & $\begin{array}{l}\text { Database of mining claim intensity: total for all claim types (lode, placer, tunnel site, and mill } \\
\text { site), by PLS section and year for Nevada, 1976-2003. }\end{array}$ \\
\hline $\begin{array}{l}\text { nv_lode.dbf, } \\
\text { nv_lode.txt }\end{array}$ & $\begin{array}{l}\text { Database of mining claim intensity totaled for lode claims, by PLS section and year for Nevada, } \\
\text { 1976-2003. }\end{array}$ \\
\hline $\begin{array}{l}\text { nv_placr.dbf, } \\
\text { nv_placr.txt }\end{array}$ & $\begin{array}{l}\text { Database of mining claim intensity totaled for placer claims, by PLS section and year for } \\
\text { Nevada, 1976-2003. }\end{array}$ \\
\hline $\begin{array}{l}\text { nv_total.dbf, } \\
\text { nv_total.txt }\end{array}$ & $\begin{array}{l}\text { Database of all mining claims for the period 1976-2003; by PLS section, claim type (lode, } \\
\text { placer, tunnel site, and mill site), and claims status (Active or Closed) at end of } 2003 \text { for } \\
\text { Nevada. }\end{array}$ \\
\hline $\begin{array}{l}\text { or_claim.dbf, } \\
\text { or_claim.txt }\end{array}$ & $\begin{array}{l}\text { Database of mining claim intensity: total for all claim types (lode, placer, tunnel site, and mill } \\
\text { site), by PLS section and year for Oregon, 1976-2003. }\end{array}$ \\
\hline $\begin{array}{l}\text { or_lode.dbf, } \\
\text { or_lode.txt }\end{array}$ & $\begin{array}{l}\text { Database of mining claim intensity totaled for lode claims, by PLS section and year for Oregon, } \\
1976-2003 .\end{array}$ \\
\hline
\end{tabular}




\begin{tabular}{|c|c|}
\hline File Name & File Description \\
\hline $\begin{array}{l}\text { or_placr.dbf, } \\
\text { or_placr.txt }\end{array}$ & $\begin{array}{l}\text { Database of mining claim intensity totaled for placer claims, by PLS section and year for } \\
\text { Oregon, 1976-2003. }\end{array}$ \\
\hline $\begin{array}{l}\text { or_total.dbf, } \\
\text { or_total.txt }\end{array}$ & $\begin{array}{l}\text { Database of all mining claims for the period 1976-2003; by PLS section, claim type (lode, } \\
\text { placer, tunnel site, and mill site), and claims status (Active or Closed) at end of } 2003 \text { for } \\
\text { Oregon. }\end{array}$ \\
\hline $\begin{array}{l}\text { ut_claim.dbf, } \\
\text { ut_claim.txt }\end{array}$ & $\begin{array}{l}\text { Database of mining claim intensity: total for all claim types (lode, placer, tunnel site, and mill } \\
\text { site), by PLS section and year for Utah, 1976-2003. }\end{array}$ \\
\hline $\begin{array}{l}\text { ut_lode.dbf, } \\
\text { ut_lode.txt }\end{array}$ & $\begin{array}{l}\text { Database of mining claim intensity totaled for lode claims, by PLS section and year for Utah, } \\
\text { 1976-2003. }\end{array}$ \\
\hline $\begin{array}{l}\text { ut_placr.dbf, } \\
\text { ut_placr.txt }\end{array}$ & $\begin{array}{l}\text { Database of mining claim intensity totaled for placer claims, by PLS section and year for Utah, } \\
\text { 1976-2003. }\end{array}$ \\
\hline $\begin{array}{l}\text { ut_total.dbf, } \\
\text { ut_total.txt }\end{array}$ & $\begin{array}{l}\text { Database of all mining claims for the period 1976-2003; by PLS section, claim type (lode, } \\
\text { placer, tunnel site, and mill site), and claims status (Active or Closed) at end of } 2003 \text { for Utah. }\end{array}$ \\
\hline $\begin{array}{l}\text { wa_claim.dbf, } \\
\text { wa_claim.txt }\end{array}$ & $\begin{array}{l}\text { Database of mining claim intensity: total for all claim types (lode, placer, tunnel site, and mill } \\
\text { site), by PLS section and year for Washington, 1976-2003. }\end{array}$ \\
\hline $\begin{array}{l}\text { wa_lode.dbf, } \\
\text { wa_lode.txt }\end{array}$ & $\begin{array}{l}\text { Database of mining claim intensity totaled for lode claims, by PLS section and year for } \\
\text { Washington, 1976-2003. }\end{array}$ \\
\hline $\begin{array}{l}\text { wa_placr.dbf, } \\
\text { wa_placr.txt }\end{array}$ & $\begin{array}{l}\text { Database of mining claim intensity totaled for placer claims, by PLS section and year for } \\
\text { Washington, 1976-2003. }\end{array}$ \\
\hline $\begin{array}{l}\text { wa_total.dbf, } \\
\text { wa_total.txt }\end{array}$ & $\begin{array}{l}\text { Database of all mining claims for the period 1976-2003; by PLS section, claim type (lode, } \\
\text { placer, tunnel site, and mill site), and claims status (Active or Closed) at end of } 2003 \text { for } \\
\text { Washington. }\end{array}$ \\
\hline $\begin{array}{l}\text { wy_claim.dbf, } \\
\text { wy_claim.txt }\end{array}$ & $\begin{array}{l}\text { Database of mining claim intensity: total for all claim types (lode, placer, tunnel site, and mill } \\
\text { site), by PLS section and year for Wyoming, 1976-2003. }\end{array}$ \\
\hline $\begin{array}{l}\text { wy_lode.dbf, } \\
\text { wy_lode.txt }\end{array}$ & $\begin{array}{l}\text { Database of mining claim intensity totaled for lode claims, by PLS section and year for } \\
\text { Wyoming, 1976-2003. }\end{array}$ \\
\hline $\begin{array}{l}\text { wy_placr.dbf, } \\
\text { wy_placr.txt }\end{array}$ & $\begin{array}{l}\text { Database of mining claim intensity totaled for placer claims, by PLS section and year for } \\
\text { Wyoming, 1976-2003. }\end{array}$ \\
\hline $\begin{array}{l}\text { wy_total.dbf, } \\
\text { wy_total.txt }\end{array}$ & $\begin{array}{l}\text { Database of all mining claims for the period 1976-2003; by PLS section, claim type (lode, } \\
\text { placer, tunnel site, and mill site), and claims status (Active or Closed) at end of } 2003 \text { for } \\
\text { Wyoming. }\end{array}$ \\
\hline
\end{tabular}

\section{Data Sources and Processing}

\section{Data Sources}

There are two kinds of data provided with this report - statistics derived from BLM mining claim records in two formats (dBASE III and ASCII), and spatial databases of Public Land Surveys in shapefile format obtained from a variety of sources. The BLM data contains records of mining claims located on Federal Lands in the United States between 1976 and 2003.

\section{Mine Claim Data}

Mining claim data was extracted from the BLM's LR2000 Oracle® database for the United States on January 15, 2004. One set of files was extracted for each of BLM's 11 administrative areas (Arizona, California, Colorado, Eastern States, Idaho, Montana, New Mexico, Nevada, Oregon, Utah, and Wyoming). These administrative areas include 16 states in which mining claims have been recorded (Arizona, Arkansas, California, Colorado, Florida, Idaho, Montana, Nebraska, New Mexico, Nevada, North Dakota, Oregon, South Dakota, Utah, Washington, and Wyoming). Arkansas and Florida data are included in the Eastern States administrative area, Nebraska in the Wyoming administrative area, North and South Dakota in the Montana administrative area, and Washington in the Oregon administrative area. 
Data from 15 tables $^{3}$ was extracted by BLM in ASCII format with | (pipe) delimiters between fields. The SQL (Structured Query Language) statements BLM used to create the tables from which the mining claim data were extracted are included in Appendix A.

At the time the data was extracted from LR2000, there were 3,102,428 claim records in the database. The number of records for each state is shown in table 2. The numbers for each state may not be entirely correct because there are errors in the LR2000 data geo_state field, from which most of these statistics were extracted. A correction to the determination of number of sections with claims in Wyoming and Nebraska was made. The geo_state field in the LR2000 data for Wyoming listed only 18 records in Nebraska. In fact, fifty-eight PLS locations (using mtrs field) are in Nebraska.

Table 2. Number of mining claim records in LR2000 database January 15, 2004 for each state.

\begin{tabular}{|l|r|}
\hline \multicolumn{1}{|c|}{ State } & $\begin{array}{c}\text { Number of claim } \\
\text { records in LR2000 }\end{array}$ \\
\hline Arizona & 358,438 \\
\hline Arkansas & 11,571 \\
\hline California & 280,494 \\
\hline Colorado & 251,486 \\
\hline Florida & 439 \\
\hline Idaho & 184,673 \\
\hline Montana & 167,213 \\
\hline Nebraska & 788 \\
\hline Nevada & 852,463 \\
\hline New Mexico & 168,678 \\
\hline North Dakota & 2 \\
\hline Oregon & 104,946 \\
\hline South Dakota & 40,730 \\
\hline Utah & 369,430 \\
\hline Washington & 52,581 \\
\hline Wyoming & 258,506 \\
\hline U.S. TOTAL & $3,102,438$ \\
\hline
\end{tabular}

There are 28 mining claim records that do not have a location within the BLM data. These are an insignificant part of the total claim record. The number of claims for each BLM administrative area that do not have a PLS location are shown in table 3. (This is shown by administrative area because some of the claims are in administrative areas that include multiple states and do not have any information on which state the claim is in.)

\footnotetext{
${ }^{3}$ Tables included: action, case_adm_agency, case_county, case_cust_sum, case_dist_ra, case_land, case_status, case_tbl, customer, decode, decode_master, legal_land_desc, status_support, remarks, and usr_commod.
} 
Table 3. Claim records in LR2000 database CASE_TBL table on January 15, 2004 that do not have a location record in the CASE_LAND table.

\begin{tabular}{|l|c|}
\hline $\begin{array}{c}\text { BLM } \\
\text { Administrative } \\
\text { Area }\end{array}$ & $\begin{array}{c}\text { Number of claims in } \\
\text { LR2000 without a } \\
\text { location }\end{array}$ \\
\hline Arizona & 5 \\
\hline California & 2 \\
\hline Colorado & 8 \\
\hline Eastern States & 1 \\
\hline Idaho & 0 \\
\hline Montana & 2 \\
\hline Nevada & 5 \\
\hline New Mexico & 1 \\
\hline Oregon & 1 \\
\hline Utah & 1 \\
\hline Wyoming & 2 \\
\hline TOTAL & 28 \\
\hline
\end{tabular}

North Dakota only has two placer claims, both active for one year only (1997). They were located in Township 139 North, Range 102 West, Section 10. These are not included in the statistical data.

\section{Spatial Data}

PLS data in a usable format do not exist in the Public Domain for the entire area covered by the LR2000 data. However, spatial datasets were obtained from a variety of sources for most of the area, although the Colorado PLS used in this project is not Public Domain. For this reason, all identifying information was stripped out of the spatial data supplied with this report and all polygons that do not have claims were deleted. The source of the individual PLS datasets is described in the associated metadata for that PLS.

\section{Processing Procedures}

\section{Mine Claim Data}

Microsoft ${ }^{\circledR}$ Access 2000 was used for this project because it is the desktop database software supplied to USGS employees. Data provided by BLM were processed by BLM administrative state to create 11 relational databases.

The procedure used to convert BLM LR2000 data to an Access database and extract statistical information was:

1. Open the compressed file obtained from BLM and extract the individual files containing the data for their respective tables ${ }^{4}$.

2. Rename the files to a Windows-based 3-digit extension filename such as the following (where $\mathrm{xx}$ is a 2 digit state identifier) ${ }^{5}$ :

a. xx.case_land.load to $\mathrm{xx}$ _case_land.txt

b. xx.case_tbl.load to xx_case_tbl.txt

3. In Access, create tables and fields with the same names and data structure as used in LR2000. See Appendix B for table names, field names, and structure used in this project.

\footnotetext{
${ }^{4}$ The files provided by BLM are in a Unix tar compress format. BLM uses a custom query to extract data from LR2000 that provides data from 12 tables, one file for each table. Only the two files listed here (a. and b.) are used in this analysis.

${ }^{5}$ The files must be renamed because the Access import wizard only recognizes files based on specific 3-digit extensions.
} 
Always check the SQL document ${ }^{6}$ provided by BLM for the latest version of the data structure. I have noticed changes in the number of fields, field names, and sizes of fields over the last few years.

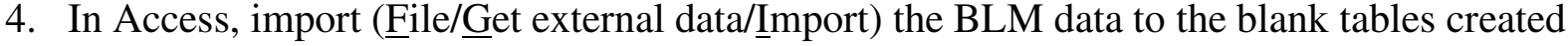
in step 3.

5. Create statistics from the raw data. This process involves running a series of queries to extract the relevant information. This can be done entirely with Access 2000 built-in functions so no programming is required. Two types of queries were used to process the raw LR2000 data for use in this study. The first set of queries, called "action queries", created a new table (MTRS_UNIQUE) and added data to four special fields in CASE_TBL table. The second type of query is a select query used to extract specific summary information from the data. The processing used after creation of the new databases with the structure of CASE_TBL shown in table B-1 was:

a. Update location_yr with the first four numbers from the $m c \_l o c \_d t$ field in CASE_TBL.

b. Update disposal_yr with data from two fields. When value in last_assess_yr = 0000 , use the first four numbers in the disp_dt field. Otherwise, update disposal_yr field with data from last_assess_yr field in CASE_TBL.

c. Query CASE_LAND table for a count of the number of sections in which a claim is registered and divide that number into one. Save the results in two fields, no_sec (count of number of sections) and fraction (fractional value) in CASE_TBL.

d. Create a table of unique mtrs values (called MTRS_UNIQUE). (Most of the statistical queries are linked to this table.)

e. Next determine the number of active mining claims in each section for a particular year. Check first that a claim was active by comparing the location year (location_yr) and abandonment year (disposal_yr). Then sum the fraction field values for all claims within each section.

f. Combine the yearly queries into a summary query for the years 1976 to 2003.

g. Export the result of this summary query to dBASE III and ASCII format files.

\section{Public Land Surveys}

The PLS spatial datasets were acquired from a variety of sources, which are documented in the metadata. Formats included both ArcGIS coverages and shapefiles in different projections. The associated polygon attribute tables had a wide range of field types and data, but all contained Public Land Survey information, to the section level. However, not all polygons contained PLS information for all polygon objects. In some spatial databases not all polygons represented a Public Land Survey grid. Such things as Land Grants, lakes, rivers, etc., when included, did not contain PLS information. A .pdf (portable document format) image is provided with each of the spatial databases showing sections that contained mining claims.

BLM data has a field (mtrs) containing an 18-character string value for the meridian, township, range, and section of any mining claim. The PLS spatial datasets that were acquired for this project did not have a field with the same meridian-township-range-section data-type as LR2000 data except for Nevada (field name lrmtrs). For those datasets, a general procedure used was to create a standardized meridian-township-range-section value in a field named mtrs, although the process to create this field varied slightly depending on the way the meridian, township, range, and section data was stored in the original database.

The field, $m t r s$, in each spatial database was populated by concatenating meridian, township, range, and section information. The string is in the format MM TTTTT RRRRR SSS

\footnotetext{
${ }^{6}$ File provided by BLM called “extract_lrdb_ddl.sql” is an ASCII file. I don't know if this will always be the name.
} 
where MM is a 2-digit numeric code for meridian, TTTTT is township value, RRRRR is range value, and SSS is a section number for any valid Public Land Survey values. Township and range are 5 characters of the form $\mathrm{XXXYZ}$ where $\mathrm{X}$ is a numeric, $\mathrm{Y}$ is 0 or 2 , and $\mathrm{Z}$ is $\mathrm{N}$ or $\mathrm{S}$ for township and $\mathrm{E}$ or $\mathrm{W}$ for range. A $\mathrm{Y}$ value of 2 means that the township or range is a fractional township or range; otherwise the value is 0 . Section is a 3-digit numeric. Any number that contains less than the maximum number of digits is left padded with zero(s) (for example, section 2 would be entered as 002, meridian 1 as 01, township 10 as 010). All fields in the spatial database except the mtrs field were then deleted.

The other standardization that was done was to project all the coverages to a common projection. For this project, the coordinate system used is geographic, and datum is set to NAD27.

There was no attempt to resolve boundary mismatches or correct coding errors between the states, with the exception of the Idaho and Montana boundary. For Idaho and Montana, spatial databases provided by Paul Hyndman in which he had modified the boundaries so that no gaps or overlaps remained and some data errors were corrected, were used.

A whole township was labeled incorrectly in the Nevada PLS spatial database. Those township labels were corrected, but not the other mtrs label errors, of which there are at least 500. Also, the resolution is supposed to be 100,000 scale, but there are instances where fractional townships are displayed on the 100,000 scale maps, but do not have polygons in this spatial database.

The mtrs field in the LR2000 data was then joined to the spatial data databases using ArcMap®. Only sections in the PLS spatial database that had corresponding sections in the mining claim database were exported to new Arc format shapefiles by state. Not all mining claim records had a corresponding spatial database polygon. Table 4 shows the number of claim records that did not have a polygon for each state. These new spatial databases for Arizona, Arkansas, California, Colorado, Florida, Idaho, Montana, Nebraska, New Mexico, Nevada, Oregon, Utah, Washington, and Wyoming are provided with this publication.

Table 4. Discrepancies in claim locations between BLM claim records and Public Land spatial databases included with this report. (NA = PLS spatial database not available).

\begin{tabular}{|l|c|c|c|c|}
\hline \multicolumn{1}{|c|}{ State } & $\begin{array}{c}\text { Number of sections } \\
\text { with claim records in } \\
\text { LR2000 }\end{array}$ & $\begin{array}{c}\text { Number of matching } \\
\text { sections in PLS } \\
\text { spatial database }\end{array}$ & $\begin{array}{c}\text { Number of claim } \\
\text { sections not in PLS } \\
\text { spatial database }\end{array}$ & $\begin{array}{c}\text { Percent of claim } \\
\text { sections without } \\
\text { polygons }\end{array}$ \\
\hline Arizona & 19,411 & 19,384 & 27 & 0.14 \\
\hline Arkansas & 537 & 439 & 98 & 18.25 \\
\hline California & 23,192 & 21,883 & 1,309 & 5.64 \\
\hline Colorado & 14,965 & 14,958 & 7 & 0.05 \\
\hline Florida & 22 & 22 & 0 & 0.00 \\
\hline Idaho & 12,251 & 12,251 & 0 & 0.00 \\
\hline Montana & 9,645 & 9,637 & 10 & 0.08 \\
\hline Nebraska & 58 & 48 & 6 & 17.24 \\
\hline Nevada & 35,334 & 35,328 & 335 & 0.00 \\
\hline New Mexico & 9,191 & 8,856 & NA & 3.64 \\
\hline North Dakota & 1 & $\mathrm{NA}$ & 162 & NA \\
\hline Oregon & 7,748 & 7,586 & $\mathrm{NA}$ & 2.09 \\
\hline South Dakota & 1,633 & $\mathrm{NA}$ & 1,604 & NA \\
\hline Utah & 20,092 & 18,488 & 219 & 7.98 \\
\hline Washington & 3,736 & 3,517 & 3,906 & 5.74 \\
\hline Wyoming & 13,672 & 13,551 & 121 & 0.89 \\
\hline U.S. TOTAL & 171,488 & 165,948 & & 2.30 \\
\hline
\end{tabular}

* Calculated from U.S. TOTAL minus North and South Dakota 
The unmatched records are probably due to one of several factors:

1. Errors and omissions in the spatial databases.

2. Data entry errors in the BLM records.

3. Location errors by the mining claimants.

Mislabeled and missing section polygons are the main reasons that all of the statistical data can not be shown spatially using the spatial databases included with this report. Most of the spatial databases had some polygons that did not contain a PLS value (mtrs). Many parts of National Forests, National Parks, and National Wildlife Refuges are unsurveyed. Claimants are required to enter a PLS value which may have been based on a projection they made that might not correspond to a Cadastral Survey projection. The Von Schmidt Boundary survey along the California-Nevada border resulted in meridians that do not conform to state boundaries and could have confused claimant when filing location notices. The PLS database for Arkansas only covered a small portion of the state probably accounting for most of the unmatched data.

Note that these shapefiles are only for use with the associated statistical data. BLM data is always changing and claims may be located in areas where BLM did not previously have a record of activity. New shapefiles should be created for any analysis involving another extraction of mining claim data from BLM's LR2000 database.

\section{Statistical Data Discussion}

Historical mining claim information has been used by industry and government to examine interest in federal land for deposits of valuable minerals. Since the early 1800's, Congress has dealt with interest by the general public in obtaining mineral rights on Federal land. In 1866 a set of rules and regulations (41 Stat.251) was promulgated that formalized the requirements for establishing a claim. The General Mining Law of May 10, 1872 established a system that is basically intact today defining four types of mining claims: lode, placer, tunnel site, and mill site.

The size of a lode mining claim is defined as "may equal, but shall not exceed, one thousand five hundred feet in length....shall extend no more than three hundred feet on each side of the middle" and "The end-lines shall be parallel to each other." The Placer Act of 1870 was amended so that "no such location shall include more than twenty acres for each individual claimant." However, an association of up to eight claimants may add 20 acres per partner to a claim up to one hundred and sixty acres total. Tunnel site claims do not directly invest a right to any acreage. A mill site can encompass up to 5 acres.

A lode claim can be up to 20.66 acres in size ( 1500 by 600 feet). In practical terms, a claimant will stake claims slightly smaller than the maximum size so as to prevent invalidation of some portion of a claim. Most placer claims are 20 acres because the claimants locate the claims by legal subdivision. Gulch placer claims and association placers may be smaller or larger.

Lode and placer claims are the only claims located on ground that is supposed to contain valuable minerals. Mill sites are supposed to cover only "non-mineral land" used for "mining and milling purposes" and tunnel site claims provide a right to drive a tunnel up to 3000 feet looking for "veins or lodes... not previously known to exist." (17 Stat. 91, The General Mining Law of 1872)

Previous work by Campbell (1996), Campbell and Hyndman (1996), and Hyndman (1999) analyzed BLM claim records and created a statistic they called "mine claim density." This statistic used a counting technique that assigned a claim record to a PLS section of land. When a claim occurred in more than one section, the count was assigned to only one of the sections. Because a claim in the CASE_TBL table that had more than one section would have multiple records in the CASE_LAND table, their technique selected the section in the first record encountered while looping through the data. In this manner, they assigned a count number to PLS sections, but in so doing did not always attach a value to all the sections in which there are claims. 
The procedure followed here uses a different approach in examining the BLM claim record data. The statistic created here is designed to convey a more accurate areal picture while not overcounting the number of claims. As such, it has its own set of assumptions. These are:

1. A claim that was reported as occurring in more than one section has a significant part of the claim in each section,

2. Based on number 1, the areal extent of a claim can be proportioned (weighted) between all the sections in which it occurs.

3. Without additional information, the only solution is to equally proportion a claim between each section in which it occurs. For example, if a claim occurred in 2 sections, half of its value would be assigned to one section and half to another.

Since the sample populations are large and the area represented by each sample is small, the error introduced by these assumptions should be minor. It should be considered more important that the spatial distribution is accurately represented, than the weighting being perfect. This allows a user to analyze spatial relationships more accurately.

It is important to realize that these statistics represent a different analysis of the BLM mine claim data than the "density" numbers created by Campbell and Hyndman (1996) and Hyndman (1999). This process may produce fractional numbers since claims occurring in multiple sections will be proportioned between all the appropriate sections. It may also produce whole numbers that represent a summation of fractional values. These numbers, can be called "claim equivalency" values, and could be considered surrogates for the area encompassed by mining claims.

Another reasonable assumption that can be made, which affects interpretation of the statistics, is that each lode or placer claim encompasses about 20 acres $^{7}$. Therefore a value of 0.5 assigned to a section would imply that claims cover approximately 10 acres of the 640 acres that make up an ideal section. Likewise, a value of 5.0 could be created by a variety of scenarios from 5 whole claims to a combination of whole and fractional claims. No matter what combination of whole and partial numbers is used to create a value of 5.0, this number can imply that 5 times 20 or 100 acres of the section have claim coverage. In this way the statistic serves a dual role. It is an indicator of how much of a section may be mineralized, while also providing a measure of intensity of interest in that section, which is more realistic than density values created by previous authors.

In the density statistics methodology, it is possible for a value of 10 to be attached to one section, with no indication that claims in that section lap into adjoining sections. That procedure gives one section extra value, while devaluing the adjoining sections. By using a weighting process, better representation of the spatial distribution of claims can be portrayed and artificial high and low values can be minimized, producing a better measure of the intensity of interest within a section.

The data used to create the statistics is imperfect. If it was perfect, there should be no more than 32 claims within a section during any year. The fact that the data has some sections with more than this number of "claim equivalents" demonstrates some of the problems. Factors that contribute to values in excess of 32 include:

- Over-staking of existing claims by other claimants,

- Claims that cover inter-claim gaps

- Claims that are smaller than twenty acres in size,

- Errors in reporting claim locations,

- Data entry errors

Large numbers usually indicate intensity of interest in the mineral potential of a section. Over-staking is common during staking rushes associated with new discoveries and around major mineral deposits. There is one known exception in Idaho. A person taught classes in staking and

\footnotetext{
${ }^{7}$ Be aware that there are fractional lode claims that are much smaller than 20.66 acres and placer claims as much as 160 acres, but these constitute a small percentage of the total number of claims.
} 
recording mining claims. The individual used a single section for recording purposes, creating an anomalously high value for that section.

Other factors that could contribute to large values in the statistics have a minor effect. Since the law now requires yearly payment to BLM for claimants holding more than 10 claims, there is little incentive to locate fractional claims. There are also some errors in reporting claim locations, since large parts of the National Forests and BLM lands are unsurveyed and claimants have to project the Public Land Survey over the area they stake. Data entry errors also occur such as case_id 8839738 in Arizona that is listed as being in 6 sections in non-adjacent townships. BLM makes a diligent effort to correct those mistakes, but they still occur.

Another problem is the determination of what constitutes an active claim. BLM lists claims as "active" or "closed" in the case_disp_txt field. This tells whether or not BLM has closed the case file, not whether the claim is active. However, they also record the last year for which assessment work was filed in the last_assess_yr field. Since the claimants must file each year, failure to file an assessment work document should void a claim. For this reason, the statistics in this report assume that the assessment year data is the best indicator of whether a claim is still active. In cases where the last_assess_yr field was blank or listed as "0000," it was necessary to use a surrogate value. In these cases, the year in the disp_dt field was used. For the most part the action associated with this date was "ABANDONMENT CLAIM VOID", "CASE CLOSED", "RELQ FILED (IN TOTAL)", or "DECLARED NULL \& VOID" so that this is considered the last possible year in which a claim was active.

In this analysis, three types of statistics were produced from LR2000 data. One type is specific to the kind of claim. There are separate yearly statistics for both active lode and placer mining claims (by PLS section). Another type of statistic is a yearly summation of all "claim" types. The numbers of each type of claim in each PLS section are added to produce a total number of active claims per section. The claim types that are summed are: lode claims, placer claims, tunnel sites, and mill sites. In a strict sense, only lode and placers are claims. It should be noted that tunnel sites are more properly considered a "means of exploration" (Maley, 1985, p. 99). Mill sites may be called "claims." However, they are mining law related actions specifically designed for "nonmineral land" (Maley, 1985, p. 104).

The third type of statistic provided with this report is a summation of the whole BLM mine recordation history; a current snapshot of activity. Three pieces of information for each PLS section are included in this statistic:

1. Activity status at end of 2003 (active or closed),

2. Claim type (lode, placer, tunnel site, or mill site),

3. Number of claim equivalents

This provides the ability to simultaneously examine relationships between activity status, claim type, and intensity of activity for the most recent data. For each PLS section up to eight records are possible; any combination of the two activity types with the four "claim" types.

The results of the statistical analysis are included with this report as four sets of database files for each state. They contain the statistical output from the respective databases created by summation queries of the data. A dBASE III (.dbf) format and a comma delimited ASCII (text) format file were created for each set of statistics. The fields and a description of the data in the associated dBASE and text files are provided in Tables 5 to 8. 
Table 5. Descriptions of fields in az_claim.dbf, ar_claim.dbf, ca_claim.dbf, co_claim.dbf, fl_claim.dbf, id_claim.dbf, mt_claim.dbf, ne_claim.dbf, nm_claim.d̄bf, nv_claim.d̄bf, or_claim.dbf, sd_claim.dbf, ut_claim.dbf, wa_claim.dbf, wy_claim.dbf and respective text files (.txt extension).

\begin{tabular}{|c|c|}
\hline \multicolumn{2}{|r|}{$\begin{array}{c}\text { xx_claim.dbf and } x x \_ \text {claim.txt } \\
\text { Tables }\end{array}$} \\
\hline Field name & Description \\
\hline MTRS & Meridian, township, range, and section concatenated string \\
\hline CLM_CT_76 & Number of active claim equivalents within a Public Land Survey section in 1976 \\
\hline CLM_CT_77 & Number of active claim equivalents within a Public Land Survey section in 1977 \\
\hline CLM_CT_78 & Number of active claim equivalents within a Public Land Survey section in 1978 \\
\hline CLM_CT_79 & Number of active claim equivalents within a Public Land Survey section in 1979 \\
\hline CLM_CT_80 & Number of active claim equivalents within a Public Land Survey section in 1980 \\
\hline CLM_CT_81 & Number of active claim equivalents within a Public Land Survey section in 1981 \\
\hline CLM_CT_82 & Number of active claim equivalents within a Public Land Survey section in 1982 \\
\hline CLM_CT_83 & Number of active claim equivalents within a Public Land Survey section in 1983 \\
\hline CLM_CT_84 & Number of active claim equivalents within a Public Land Survey section in 1984 \\
\hline CLM_CT_85 & Number of active claim equivalents within a Public Land Survey section in 1985 \\
\hline CLM_CT_86 & Number of active claim equivalents within a Public Land Survey section in 1986 \\
\hline CLM_CT_87 & Number of active claim equivalents within a Public Land Survey section in 1987 \\
\hline CLM_CT_88 & Number of active claim equivalents within a Public Land Survey section in 1988 \\
\hline CLM_CT_89 & Number of active claim equivalents within a Public Land Survey section in 1989 \\
\hline CLM_CT_90 & Number of active claim equivalents within a Public Land Survey section in 1990 \\
\hline CLM_CT_91 & Number of active claim equivalents within a Public Land Survey section in 1991 \\
\hline CLM_CT_92 & Number of active claim equivalents within a Public Land Survey section in 1992 \\
\hline CLM_CT_93 & Number of active claim equivalents within a Public Land Survey section in 1993 \\
\hline CLM_CT_94 & Number of active claim equivalents within a Public Land Survey section in 1994 \\
\hline CLM_CT_95 & Number of active claim equivalents within a Public Land Survey section in 1995 \\
\hline CLM_CT_96 & Number of active claim equivalents within a Public Land Survey section in 1996 \\
\hline CLM_CT_97 & Number of active claim equivalents within a Public Land Survey section in 1997 \\
\hline CLM_CT_98 & Number of active claim equivalents within a Public Land Survey section in 1998 \\
\hline CLM_CT_99 & Number of active claim equivalents within a Public Land Survey section in 1999 \\
\hline CLM_CT_00 & Number of active claim equivalents within a Public Land Survey section in 2000 \\
\hline CLM_CT_01 & Number of active claim equivalents within a Public Land Survey section in 2001 \\
\hline CLM_CT_02 & Number of active claim equivalents within a Public Land Survey section in 2002 \\
\hline CLM_CT_03 & Number of active claim equivalents within a Public Land Survey section in 2003 \\
\hline
\end{tabular}

Table 6. Descriptions of fields in az_lode.dbf, ar_lode.dbf, ca_lode.dbf, co_lode.dbf, fl_lode.dbf, id_lode.dbf, mt_lode.dbf, ne_lode.dbf, nm_lode.dbf, nv_lode.dbf, or_lode.dbf, sd_lode.dbf, ut_lode.dbf, wa_lode.dbf, wy_lode.dbf and respective text files (.txt extension).

\begin{tabular}{|l|l|}
\hline \multicolumn{2}{|c|}{$\begin{array}{c}\text { xx_lode.dbf and xx_lode.txt } \\
\text { Tables }\end{array}$} \\
\hline Field name & Description \\
\hline MTRS & Meridian, township, range, and section concatenated string \\
\hline LD_CT_76 & Number of active lode claim equivalents within a Public Land Survey section in 1976 \\
\hline LD_CT_77 & Number of active lode claim equivalents within a Public Land Survey section in 1977 \\
\hline LD_CT_78 & Number of active lode claim equivalents within a Public Land Survey section in 1978 \\
\hline LD_CT_79 & Number of active lode claim equivalents within a Public Land Survey section in 1979 \\
\hline LD_CT_80 & Number of active lode claim equivalents within a Public Land Survey section in 1980 \\
\hline LD_CT_81 & Number of active lode claim equivalents within a Public Land Survey section in 1981 \\
\hline LD_CT_82 & Number of active lode claim equivalents within a Public Land Survey section in 1982 \\
\hline LD_CT_83 & Number of active lode claim equivalents within a Public Land Survey section in 1983 \\
\hline LD_CT_84 & Number of active lode claim equivalents within a Public Land Survey section in 1984 \\
\hline LD_CT_85 & Number of active lode claim equivalents within a Public Land Survey section in 1985 \\
\hline LD_CT_86 & Number of active lode claim equivalents within a Public Land Survey section in 1986 \\
\hline LD_CT_87 & Number of active lode claim equivalents within a Public Land Survey section in 1987 \\
\hline LD_CT_88 & Number of active lode claim equivalents within a Public Land Survey section in 1988 \\
\hline
\end{tabular}




\begin{tabular}{|l|l|}
\hline LD_CT_89 & Number of active lode claim equivalents within a Public Land Survey section in 1989 \\
\hline LD_CT_90 & Number of active lode claim equivalents within a Public Land Survey section in 1990 \\
\hline LD_CT_91 & Number of active lode claim equivalents within a Public Land Survey section in 1991 \\
\hline LD_CT_92 & Number of active lode claim equivalents within a Public Land Survey section in 1992 \\
\hline LD_CT_93 & Number of active lode claim equivalents within a Public Land Survey section in 1993 \\
\hline LD_CT_94 & Number of active lode claim equivalents within a Public Land Survey section in 1994 \\
\hline LD_CT_95 & Number of active lode claim equivalents within a Public Land Survey section in 1995 \\
\hline LD_CT_96 & Number of active lode claim equivalents within a Public Land Survey section in 1996 \\
\hline LD_CT_97 & Number of active lode claim equivalents within a Public Land Survey section in 1997 \\
\hline LD_CT_98 & Number of active lode claim equivalents within a Public Land Survey section in 1998 \\
\hline LD_CT_99 & Number of active lode claim equivalents within a Public Land Survey section in 1999 \\
\hline LD_CT_00 & Number of active lode claim equivalents within a Public Land Survey section in 2000 \\
\hline LD_CT_01 & Number of active lode claim equivalents within a Public Land Survey section in 2001 \\
\hline LD_CT_02 & Number of active lode claim equivalents within a Public Land Survey section in 2002 \\
\hline LD_CT_03 & Number of active lode claim equivalents within a Public Land Survey section in 2003 \\
\hline
\end{tabular}

Table 7. Descriptions of fields in az_placr.dbf, ar_placr.dbf, ca_placr.dbf, co_placr.dbf, fl_placr.dbf, id_placr.dbf, mt_placr.dbf, ne_placr.dbf, nm_placr.dbf, nv_placr.dbf, or_placr.dbf, sd_placr.dbf, ut_placr.dbf, wa_placr.dbf, wy_placr.dbf and respective text files (.txt extension).

\begin{tabular}{|c|c|}
\hline \multicolumn{2}{|r|}{$\begin{array}{c}x x \_ \text {placr.dbf and } x x \_p l a c r . t x t \\
\text { Tables }\end{array}$} \\
\hline Field name & Description \\
\hline MTRS & Meridian, township, range, and section concatenated string \\
\hline PC_CT_76 & Number of active placer claim equivalents within a Public Land Survey section in 1976 \\
\hline PC_CT_77 & Number of active placer claim equivalents within a Public Land Survey section in 1977 \\
\hline PC_CT_78 & Number of active placer claim equivalents within a Public Land Survey section in 1978 \\
\hline PC_CT_79 & Number of active placer claim equivalents within a Public Land Survey section in 1979 \\
\hline PC_CT 80 & Number of active placer claim equivalents within a Public Land Survey section in 1980 \\
\hline PC_CT_81 & Number of active placer claim equivalents within a Public Land Survey section in 1981 \\
\hline PC_CT_82 & Number of active placer claim equivalents within a Public Land Survey section in 1982 \\
\hline PC_CT_83 & Number of active placer claim equivalents within a Public Land Survey section in 1983 \\
\hline PC_CT_84 & Number of active placer claim equivalents within a Public Land Survey section in 1984 \\
\hline PC_CT_85 & Number of active placer claim equivalents within a Public Land Survey section in 1985 \\
\hline PC_CT_86 & Number of active placer claim equivalents within a Public Land Survey section in 1986 \\
\hline PC_CT_87 & Number of active placer claim equivalents within a Public Land Survey section in 1987 \\
\hline PC_CT_88 & Number of active placer claim equivalents within a Public Land Survey section in 1988 \\
\hline PC_CT_89 & Number of active placer claim equivalents within a Public Land Survey section in 1989 \\
\hline PC_CT_90 & Number of active placer claim equivalents within a Public Land Survey section in 1990 \\
\hline PC_CT_91 & Number of active placer claim equivalents within a Public Land Survey section in 1991 \\
\hline PC_CT_92 & Number of active placer claim equivalents within a Public Land Survey section in 1992 \\
\hline PC_CT_93 & Number of active placer claim equivalents within a Public Land Survey section in 1993 \\
\hline PC_CT 94 & Number of active placer claim equivalents within a Public Land Survey section in 1994 \\
\hline PC_CT_95 & Number of active placer claim equivalents within a Public Land Survey section in 1995 \\
\hline PC_CT_96 & Number of active placer claim equivalents within a Public Land Survey section in 1996 \\
\hline PC_CT 97 & Number of active placer claim equivalents within a Public Land Survey section in 1997 \\
\hline PC_CT_98 & Number of active placer claim equivalents within a Public Land Survey section in 1998 \\
\hline PC_CT_99 & Number of active placer claim equivalents within a Public Land Survey section in 1999 \\
\hline PC_CT_00 & Number of active placer claim equivalents within a Public Land Survey section in 2000 \\
\hline PC_CT_01 & Number of active placer claim equivalents within a Public Land Survey section in 2001 \\
\hline PC_CT_02 & Number of active placer claim equivalents within a Public Land Survey section in 2002 \\
\hline PC_CT_03 & Number of active placer claim equivalents within a Public Land Survey section in 2003 \\
\hline
\end{tabular}


Table 8. Descriptions of fields in az_total.dbf, ar_total.dbf, ca_total.dbf, co_total.dbf, fl_total.dbf, id_total.dbf, mt_total.dbf, ne_total.dbf, nm_total.dbf, nv_total.dbf, or_total.dbf, sd_total.dbf, ut_total.dbf, wa_total.dbf, wy_total.dbf and respective text files (.txt extension).

\begin{tabular}{|c|c|}
\hline \multicolumn{2}{|r|}{$\begin{array}{c}\text { xx_total.dbf and } x x \_t o t a l . t x t \\
\text { Tables }\end{array}$} \\
\hline Field name & Description \\
\hline MTRS & Meridian, township, range, and section concatenated string \\
\hline CASE_DISP & Case disposition - Active (A) or closed (C) \\
\hline CASETYPE_T & $\begin{array}{l}\text { Type of mining claim - LODE CLAIM (claim that contains a vein or lode), LODE CLAIM- } \\
\text { NP (lode claim in a national park), PLACER CLAIM (claim on all forms of mineral deposit } \\
\text { not covered by lode claims), MILL SITE CLAIM (claim on non-mineral land used for mining } \\
\text { or milling purposes), or TUNNEL SITE (entrance to a tunnel used for exploration of hidden } \\
\text { veins or lodes) }\end{array}$ \\
\hline CLAIM_EQUIV & Number of claim equivalents in the section. \\
\hline
\end{tabular}

\section{GIS Documentation}

All the spatial datasets are shapefiles containing polygons; and are in geographic coordinates, NAD27 datum. The shapefiles are named az_claims03, ar_claims03, ca_claims03, co_claims03, fl_claims03, id_claims03, mt_claims03, ne_claims03, nm_claims03, nv_claims03, or_claims03, ut_claims03, wa_claims03, and wy_claims03. The shapefiles contain one field, mtrs, which is in the same format as the mtrs field in the associated relational databases and text files (table 9). General metadata applicable to all the datasets is in Appendix C. Individual metadata for each shapefile is included as an .xml file embedded in the respective shapefile.

Table 9. Description of additional field in az_pls_03.dbf, ar_pls_03.dbf, ca_pls_03.dbf, co_pls_03.dbf, fl_pls_03.dbf, id_pls_03.dbf, mt_pls_03.dbf, ne_pls_03.dbf, nm_pls_03.dbf, nv_pls_03.dbf, or_pls_03.dbf, ut_pls_03.dbf, wa_pls_03.dbf, wy_pls_03.dbf.

\begin{tabular}{|l|l|}
\hline \multicolumn{1}{|c|}{ Field Name } & Description \\
\hline MTRS & Meridian, township, range, and section concatenated string \\
\hline
\end{tabular}

\section{User procedures}

In order to use the data in a spatial context, the relational data must be joined to the spatial databases in a geographic information system. There are two ways to connect the databases: join or relate/link. In ArcMap, data can be joined or relate/linked, using either the dBASE format or $\mathrm{ASCII}^{8}$ (text) format files, to the appropriate spatial database on the common field (mtrs). All of the files with names like xx_claim, xx_lode, and xx_placer should be connected using a join. The files xx_total should be connected in a geographic information system using link or relate since they have a one-to-many relationship.

Statistical data joined to spatial data allows the visual presentation of the statistical data. Variation in both distributions of claims and intensity of activity can be displayed and used for analysis. For example, with lode mine claim intensity statistical data (az_lode.dbf) joined to the Arizona spatial data (az_pls_03) you can symbolize and display individual years. The variation between 1979 and 1992 is shown in figure 2. Note the mining claim interest in northwest Arizona was small in the 1970's, very intense in the 1980's, and declined rapidly in the 1990's. This data shows not only where there is mining interest during a particular year, but also shows the change in interest over time.

\footnotetext{
${ }^{8}$ Generally the text format files process much slower in spatial database software.
} 

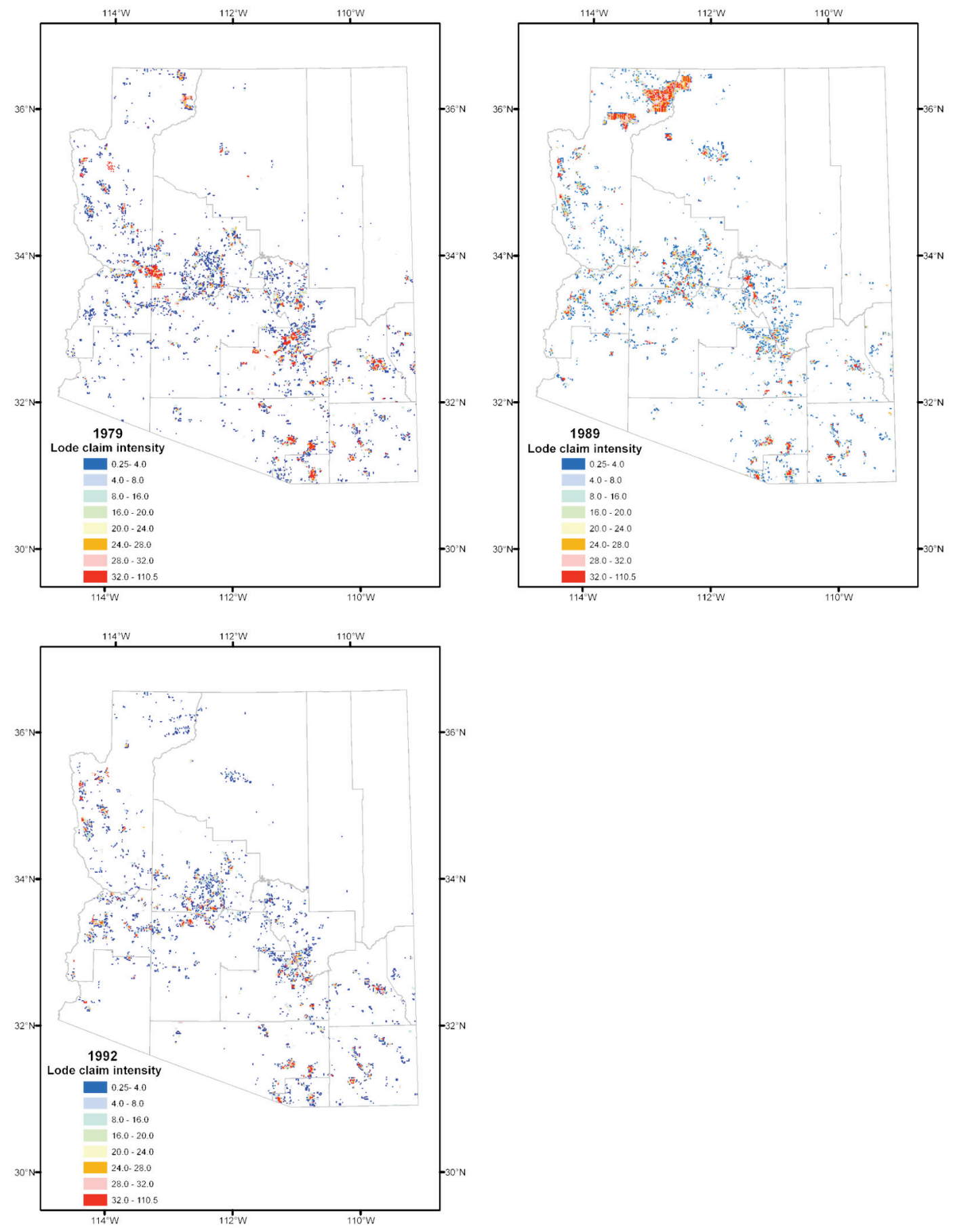

Figure 2. Areas in Arizona containing active lode mining claims in 1979, 1989, and 1992 categorized by intensity (number of claims) within a Public Land Survey section. 
The totals data allows queries to show the location of claims meeting specific criteria at the end of 2003. For example, linking id_total.dbf to the Idaho PLS (id_pls_03) provides the ability to ask a question such as "where are all sections that have had more than 4 mill sites that have been abandoned before 2003?" The results of such a query are shown in figure 3 . Other questions can be asked such as: "where are all sections that have closed claims in 2003" or "which sections contain both mill site and lode claims?"

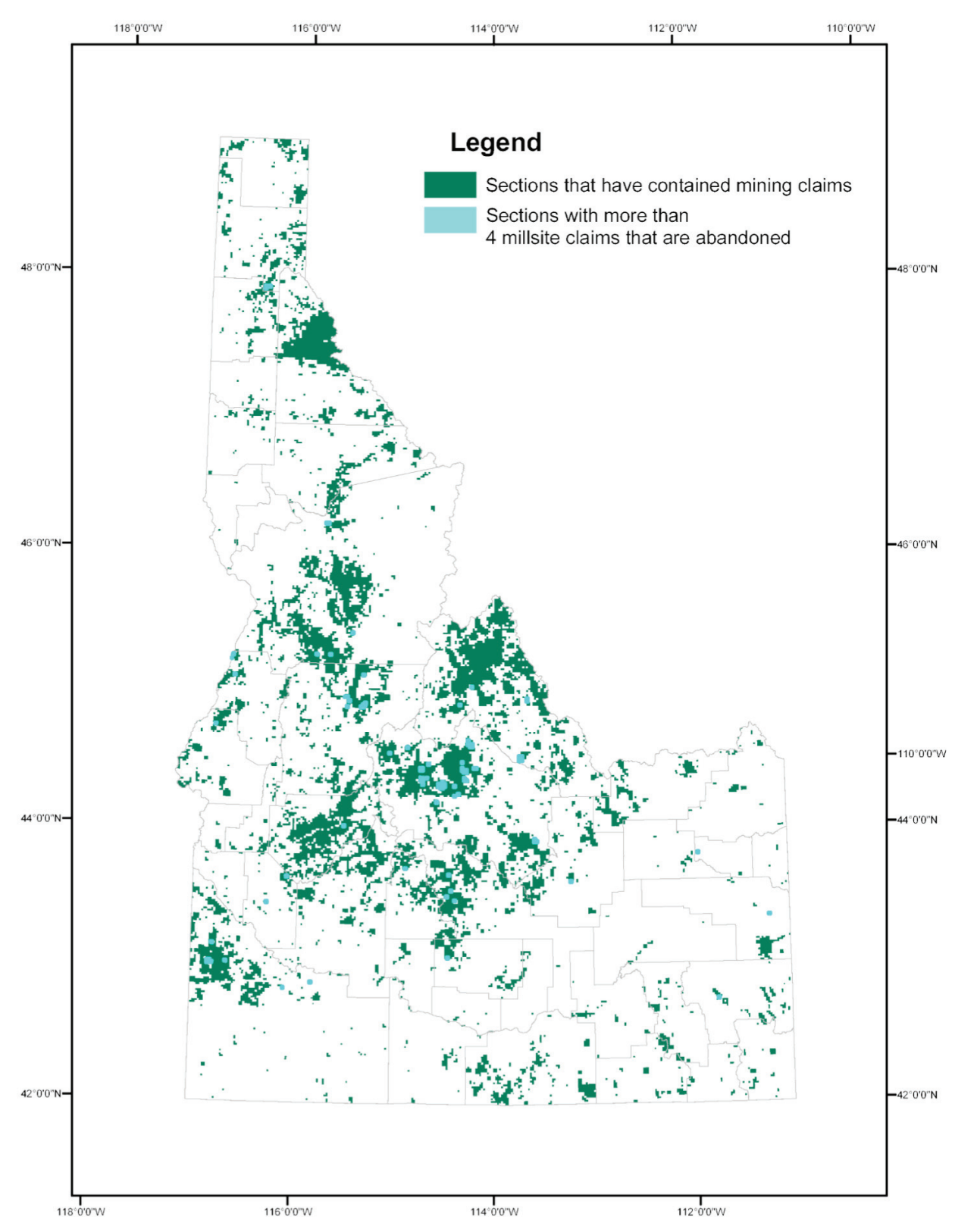

Figure 3. Public Land Survey sections in Idaho containing more than 4 mill site claims that were abandoned before 2004. 
The above descriptions are examples of some of the kinds of information that can be extracted from BLM mining claim records. Some compromises have to be made due to data limitations, but at regional scales, trends and patterns can be discerned that allow this data to be useful for analysis. It can also be combined with similar resolution data to answer a myriad of other questions.

\section{Obtaining Digital Data}

The spatial databases are available in shapefile format with associated data files. The spatial data is maintained in:

Projection: Geographic

Units: Decimal Degrees

Datum: NAD27

Spheroid: Clarke1866

To obtain copies of the digital data:

- Download from the USGS World Wide Web site: URL = http://pubs.usgs.gov/ds/124

Note that the uncompressed files take over 400 megabytes of space.

These Internet sites contain the spatial data, associated .dbf and .txt format tables, and metadata for the state PLS spatial databases (see listing of files in Appendix D). Formatted metadata (Federal Geographic Data Committee-compliant) is included with each spatial database.

To manipulate the spatial databases, you must have software that is capable of reading shapefile format.

\section{References Cited}

Campbell, H.W., 1996, Procedure for making a mining claim density map from BLM claim recordation digital data: U.S. Geological Survey Open-File Report 96-736, 13 p., URL: http://pubs.usgs.gov/of/1996/of96-736/.

Campbell, H.W., and Hyndman, P.C., 1996, Digital mining claim density map for Federal lands in the Pacific Northwest: U.S. Geological Survey Open-File Report 96-737, 11 p., URL: http://pubs.usgs.gov/of/1996/of96-737/.

Hyndman, P.C., and Campbell, H.W., 1999, Digital Databases Containing Mining Claim Density Information for Arizona, California, Colorado, Idaho, Montana, Nebraska, New Mexico, Nevada, Oregon, South Dakota, Utah, Washington, and Wyoming Created From the BLM Mining Claim Recordation System: 1996: U.S. Geological Survey Open-File Report 99-325, Online version 1.0, URL: http://pubs.usgs.gov/of/1999of99-325/.

Maley, T.S., 1985, Mining Law: Mineral Land Publications, Boise, Idaho, 597 p. 


\section{Appendix A - Table Design SOL (Structured Query Language)}

The following SQL statement provided by BLM shows how the case_tbl and case_land tables were created in LR2000 and table structure as it existed on January 15, 2003. This SQL is Oracle ${ }^{\circledR}$ specific. The SQL language may have to be modified to create the same tables in other relational database programs.

BLM did not provide any description or definitions for the fields in their database. Questions concerning metadata and definitions for the tables and fields in LR2000 should be directed to the BLM (http://www.blm.gov/lr2000/).

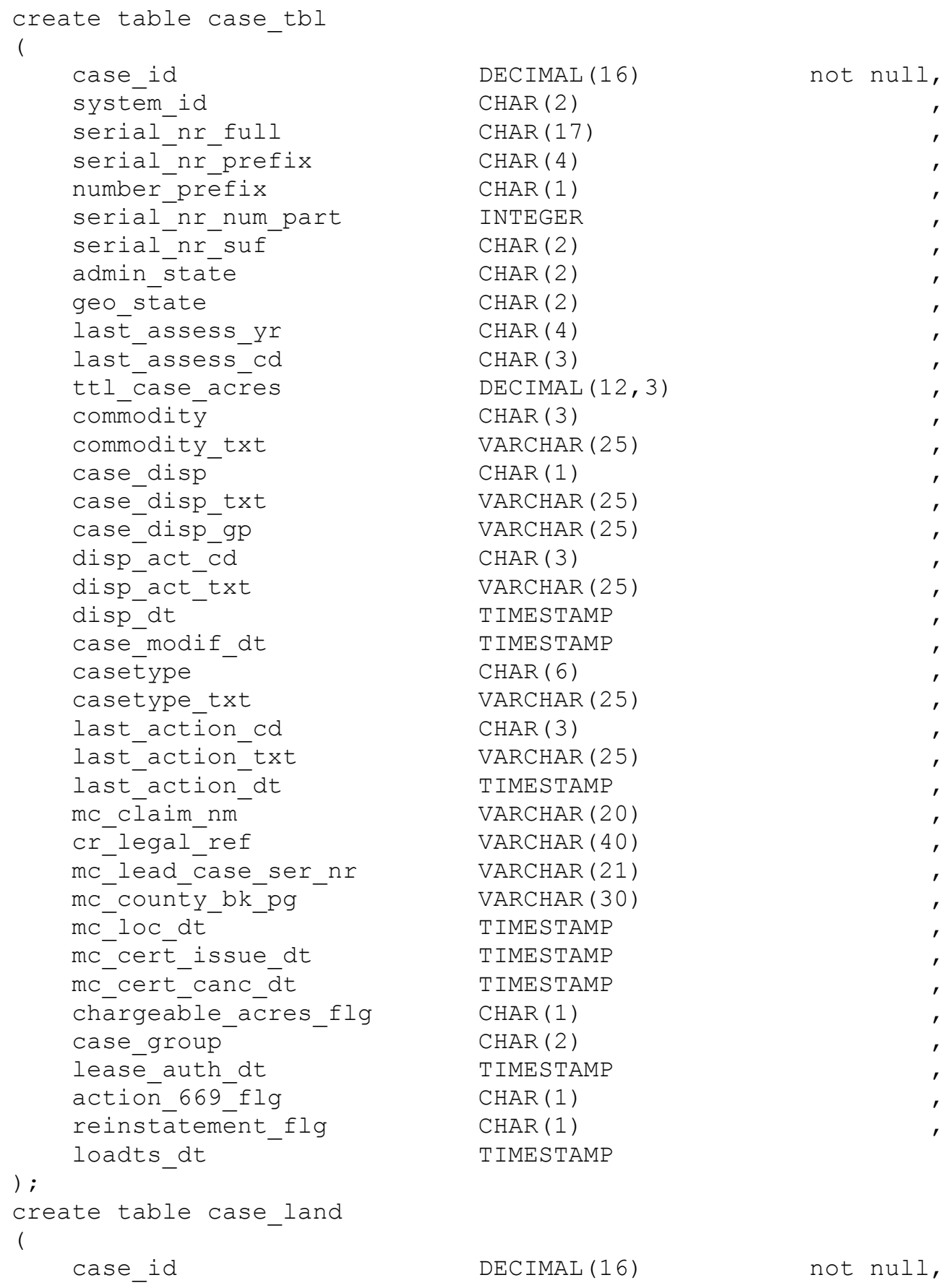




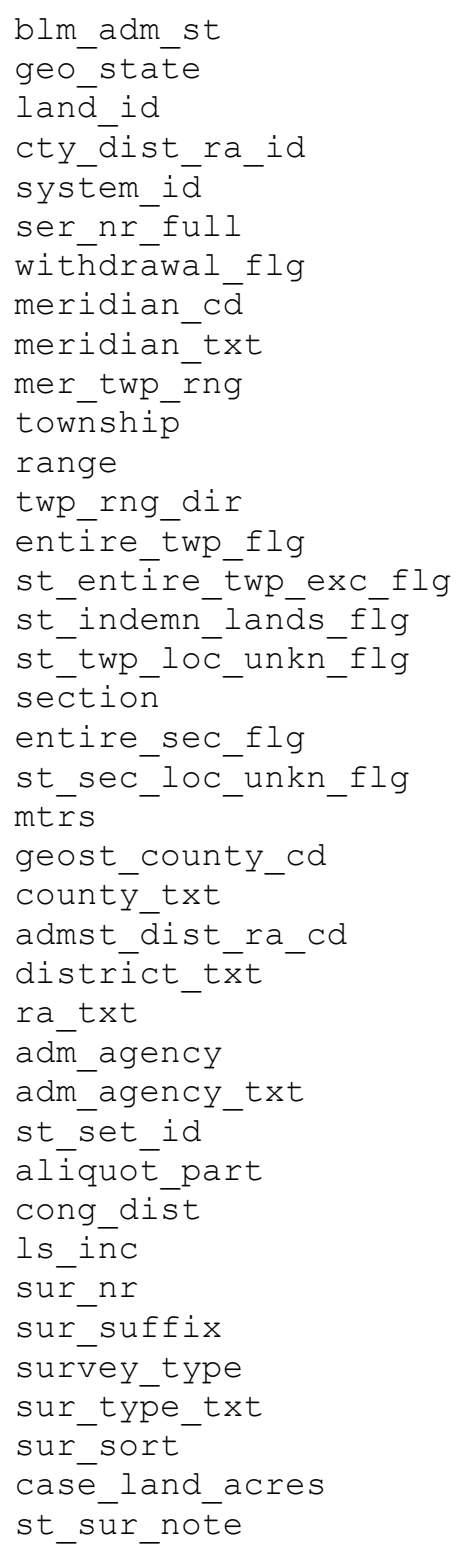

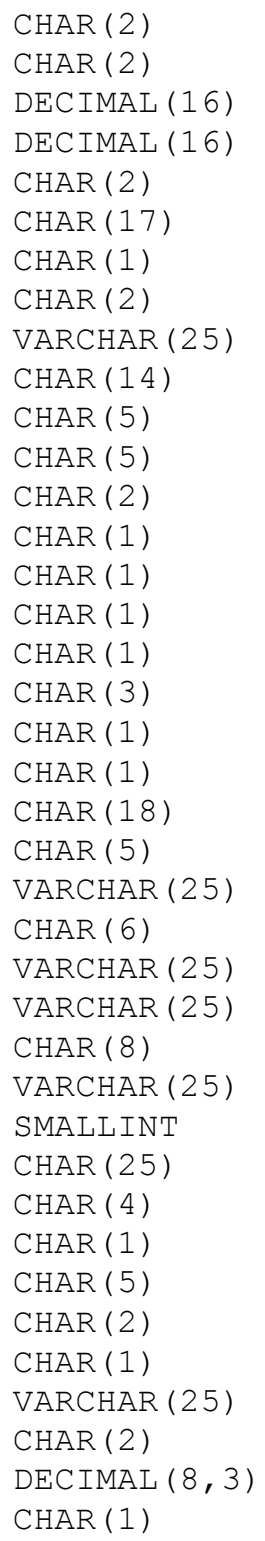

CHAR (2)

CHAR (2)

DECIMAL (16)

DECIMAL ( 16 )

CHAR (2)

CHAR ( 17 )

CHAR (1)

CHAR (2)

VARCHAR (25)

CHAR (14)

CHAR ( 5 )

CHAR ( 5 )

CHAR (2)

CHAR (1)

CHAR (1)

CHAR (1)

CHAR (1)

CHAR (3)

CHAR (1)

CHAR (1)

CHAR (18)

CHAR (5)

VARCHAR (25)

CHAR ( 6 )

VARCHAR (25)

VARCHAR (25)

CHAR ( 8)

VARCHAR (25)

SMALLINT

CHAR (25)

CHAR ( 4 )

CHAR (1)

CHAR ( 5 )

CHAR (2)

CHAR (1)

VARCHAR (25)

CHAR (2)

$\operatorname{DECIMAL}(8,3)$

CHAR (1)

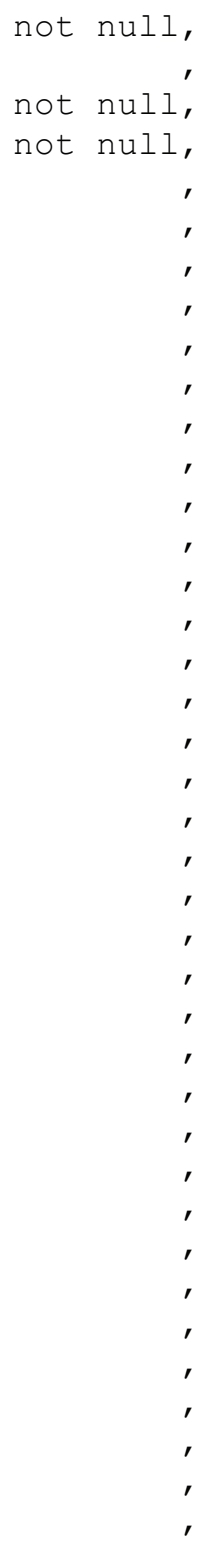




\section{Appendix B - Access 2000 Table Design}

ASCII text files supplied by BLM were imported into a Microsoft Access 2000 database. Using the names and data types provided in the table creation SQL supplied by BLM (Appendix A), a similar data design was created in Access. Additional fields necessary for statistical processing were also added to the design. The Access design is provided in tables B-1 and B-2. Fields created specifically for this project are described in the Description column. The remaining fields were supplied by BLM without any definitions.

Data for one look-up table (case_disp, table B-3) was also provided that gives values for codes in the case_disp field of the CASE_TBL table.

The following tables can be used to reconstruct the Access 2000 database used to create the information provided with this report. Since BLM is constantly updating their data and correcting errors in older data, new downloads of the database may provide slightly different yearly results from those included in this data release.

Table B-1. CASE_TBL table structure

\begin{tabular}{|l|l|l|l|}
\hline \multicolumn{1}{|c|}{ Tield Name } & Type & \multicolumn{1}{c|}{ Size } & \\
\hline Case_id & Number & Long Integer & BLM defined field \\
\hline System_id & Text & 2 & BLM defined field \\
\hline Serial_nr_full & Text & 17 & BLM defined field \\
\hline Serial_nr_prefix & Text & 4 & BLM defined field \\
\hline Number_prefix & Text & 1 & BLM defined field \\
\hline Serial_nr_num_part & Number & Long Integer & BLM defined field \\
\hline Serial_nr_suf & Text & 2 & BLM defined field \\
\hline Admin_state & Text & 2 & BLM defined field \\
\hline Geo_state & Text & 2 & BLM defined field \\
\hline Last_assess_yr & Text & 4 & BLM defined field \\
\hline Last_assess_cd & Text & 3 & BLM defined field \\
\hline Ttl_case_acres & Number & Double & BLM defined field \\
\hline Commodity & Text & 3 & BLM defined field \\
\hline Commodity_txt & Text & 25 & BLM defined field \\
\hline Case_disp & Text & 1 & BLM defined field \\
\hline Case_disp_txt & Text & 25 & BLM defined field \\
\hline Case_disp_gp & Text & 25 & BLM defined field \\
\hline Disp_act_cd & Text & 3 & BLM defined field \\
\hline Disp_act_txt & Text & 25 & BLM defined field \\
\hline Disp_dt & Text & 25 & BLM defined field \\
\hline Case_modif_dt & Text & 25 & BLM defined field \\
\hline Casetype & Text & 6 & BLM defined field \\
\hline Casetype_txt & Text & 25 & BLM defined field \\
\hline Last_action_cd & Text & 3 & BLM defined field \\
\hline Last_action_txt & Text & 25 & BLM defined field \\
\hline Last_action_dt & Text & 25 & BLM defined field \\
\hline Mc_claim_nm & Text & 20 & BLM defined field \\
\hline Cr_legal_ref & Text & 40 & BLM defined field \\
\hline Mc_lead_case_ser_nr & Text & 17 & BLM defined field \\
\hline Mc_county_bk_pg & Text & 30 & BLM defined field \\
\hline Mc_loc_dt & Text & 25 & BLM defined field \\
\hline Mc_cert_issue_dt & Text & 25 & BLM defined field \\
\hline Mc_cert_canc_dt & Text & 25 & BLM defined field \\
\hline Chargeable_acres_flg & Text & 1 & BLM defined field \\
\hline Case_group & Text & 2 & BLM defined field \\
\hline Leas_aath_dt & Text & 25 & BLM defined field \\
\hline Action_669_flg & Text & 1 & BLM defined field \\
\hline & & & \\
\hline
\end{tabular}




\begin{tabular}{|l|l|l|l|}
\hline \multicolumn{1}{|c|}{ Field Name } & \multicolumn{1}{c|}{ Type } & \multicolumn{1}{c|}{ Size } & \multicolumn{1}{c|}{ Description } \\
\hline Reinstatement_flg & Text & 1 & BLM defined field \\
\hline load_dt & Text & 25 & BLM defined field \\
\hline location_yr & Number & Integer & $\begin{array}{l}\text { Year (four-digit form) mining claim was located } \\
\text { (non-BLM field) }\end{array}$ \\
\hline disposal_yr & Number & Integer & $\begin{array}{l}\text { Last year (four-digit form) mining claim was active } \\
\text { (non-BLM field) }\end{array}$ \\
\hline no_sec & Number & Integer & $\begin{array}{l}\text { Number of sections in which the claim is situated. } \\
\text { (non-BLM field) }\end{array}$ \\
\hline fraction & Number & Double & 1/no_sec (non-BLM field) \\
\hline
\end{tabular}

Table B-2. CASE LAND tables structure

\begin{tabular}{|c|c|c|c|}
\hline Field Name & Type & Size & Description \\
\hline Case_id & Number & Long Integer & BLM defined field \\
\hline Blm_adm_state & Text & 2 & BLM defined field \\
\hline Geo_state & Text & 2 & BLM defined field \\
\hline Land_id & Number & 16 & BLM defined field \\
\hline Cty_dist_ra_id & Number & 16 & BLM defined field \\
\hline System_id & Text & 2 & BLM defined field \\
\hline Ser_nr_full & Text & 15 & BLM defined field \\
\hline Withdrawal_flg & Text & 1 & BLM defined field \\
\hline Meridian_cd & Text & 2 & BLM defined field \\
\hline Meridian_txt & Text & 25 & BLM defined field \\
\hline Mer_twp_rng & Text & 14 & BLM defined field \\
\hline Township & Text & 5 & BLM defined field \\
\hline Range & Text & 5 & BLM defined field \\
\hline Twp_rng_dir & Text & 2 & BLM defined field \\
\hline Entire_twp_flg & Text & 1 & BLM defined field \\
\hline St_entire_twp_exc_flg & Text & 1 & BLM defined field \\
\hline St_indemn_lands_flg & Text & 1 & BLM defined field \\
\hline St_twp_loc_unkn_flg & Text & 1 & BLM defined field \\
\hline Section & Text & 1 & BLM defined field \\
\hline Entire_sec_flg & Text & 3 & BLM defined field \\
\hline St_sec_loc_unkn_flg & Text & 1 & BLM defined field \\
\hline Mtrs & Text & 18 & BLM defined field \\
\hline Geostate_county_cd & Text & 5 & BLM defined field \\
\hline County_txt & Text & 25 & BLM defined field \\
\hline Admst_dist_ra_cd & Text & 6 & BLM defined field \\
\hline District_txt & Text & 25 & BLM defined field \\
\hline Ra_txt & Text & 25 & BLM defined field \\
\hline Adm_agency & Text & 8 & BLM defined field \\
\hline Adm_agency_txt & Text & 25 & BLM defined field \\
\hline St_set_id & Number & Integer & BLM defined field \\
\hline Aliquot_part & Text & 25 & BLM defined field \\
\hline Cong_dist & Text & 4 & BLM defined field \\
\hline Ls_inc & Text & 1 & BLM defined field \\
\hline Sur_nr & Text & 5 & BLM defined field \\
\hline Sur_suffix & Text & 2 & BLM defined field \\
\hline Survey_type & Text & 1 & BLM defined field \\
\hline Sur_type_txt & Text & 25 & BLM defined field \\
\hline Sur_sort & Number & 2 & BLM defined field \\
\hline Case_land_acres & Number & Double & BLM defined field \\
\hline St_sur_note & Text & 1 & BLM defined field \\
\hline
\end{tabular}


Table B-3. Mining claim case_disp codes in CASE_TBL table

\begin{tabular}{|l|l|}
\hline case_disp & \multicolumn{1}{c|}{ case_disp_txt } \\
\hline A & CASE IS ACTIVE \\
\hline C & CASE IS CLOSED, NO FURTHER ACTION \\
\hline I & INSUFFICIENT INFORMATION ON CASE \\
\hline V & SERIAL NUMBER HAS BEEN VOIDED \\
\hline
\end{tabular}

